\title{
Global marine plankton functional type biomass distributions: coccolithophores
}

\author{
C. J. O'Brien ${ }^{1}$, J. A. Peloquin ${ }^{1}$, M. $\operatorname{Vogt}^{1}$, M. Heinle ${ }^{2}$, N. Gruber ${ }^{1}$, P. Ajani ${ }^{3}$, H. Andruleit ${ }^{4}$, J. Arístegui ${ }^{5}$, \\ L. Beaufort ${ }^{6}$, M. Estrada ${ }^{7}$, D. Karentz ${ }^{8}$, E. Kopczyńska ${ }^{9}$, R. Lee ${ }^{10}$, A. J. Poulton ${ }^{11}$, T. Pritchard ${ }^{12}$, and \\ C. Widdicombe ${ }^{13}$ \\ ${ }^{1}$ Environmental Physics Group, Institute for Biogeochemistry and Pollutant Dynamics, ETH Zürich, \\ Universitätsstrasse 16, 8092 Zurich, Switzerland \\ ${ }^{2}$ Laboratory for Global Marine and Atmospheric Chemistry, School of Environmental Sciences, \\ University of East Anglia, Norwich, NR4 7TJ, UK \\ ${ }^{3}$ Department of Biological Sciences, Macquarie University, North Ryde, NSW, 2109, Australia \\ ${ }^{4}$ Bundesanstalt für Geowissenschaften und Rohstoffe (BGR), Geozentrum Hannover, \\ Stilleweg 2, 30655 Hannover, Germany \\ ${ }^{5}$ Instituto de Oceanografía y Cambio Global (IOCAG), Universidad de Las Palmas de Gran Canaria, \\ 35017, Las Palmas de Gran Canaria, Spain \\ ${ }^{6}$ Centre Européen de Recherche et d'Enseignement des Géosciences de l'Environnement (CEREGE), \\ CNRS/Aix-Marseille Univ., Ave. Louis Philibert, 13545 Aix en Provence, France \\ ${ }^{7}$ Institut de Ciencies del MAR (CSIC), Passeig Maritim de la Barceloneta, 3749, \\ 08003 Barcelona, Catalunya, Spain \\ ${ }^{8}$ University of San Francisco, College of Arts and Sciences, 2130 Fulton Street, San Francisco, CA 94117, USA \\ ${ }^{9}$ Institute of Biochemistry and Biophysics, Department of Antarctic Biology, Polish Academy of Sciences, \\ Ustrzycka 10/12, 02-141 Warsaw, Poland \\ ${ }^{10}$ Centre for Environmental Science, EPA Victoria, Ernest Jones Drive, Macleod VIC 3085, Australia \\ ${ }^{11}$ National Oceanography Centre Southampton, University of Southampton, UK \\ ${ }^{12}$ Waters and Coastal Science Section, Office of Environment and Heritage, P.O. Box A290, \\ Sydney South NSW 1232, Australia \\ ${ }^{13}$ Plymouth Marine Laboratory, Prospect Place, The Hoe, Plymouth PL1 3DH, UK \\ Correspondence to: C. J. O’Brien (colleen.obrien@env.ethz.ch)
}

Received: 29 June 2012 - Published in Earth Syst. Sci. Data Discuss.: 24 July 2012

Revised: 19 June 2013 - Accepted: 20 June 2013 - Published: 12 July 2013

\begin{abstract}
Coccolithophores are calcifying marine phytoplankton of the class Prymnesiophyceae. They are considered to play an import role in the global carbon cycle through the production and export of organic carbon and calcite. We have compiled observations of global coccolithophore abundance from several existing databases as well as individual contributions of published and unpublished datasets. We make conservative estimates of carbon biomass using standardised conversion methods and provide estimates of uncertainty associated with these values. The quality-controlled database contains 57321 individual observations at various taxonomic levels. This corresponds to 11503 observations of total coccolithophore abundance and biomass. The data span a time period of 1929-2008, with observations from all ocean basins and all seasons, and at depths ranging from the surface to $500 \mathrm{~m}$. Highest biomass values are reported in the North Atlantic, with a maximum of $127.2 \mu \mathrm{gCL}{ }^{-1}$. Lower values are reported for the Pacific (maximum of $20.0 \mu \mathrm{gCL}^{-1}$ ) and Indian Ocean (up to $45.2 \mu \mathrm{gCL}^{-1}$ ). Maximum biomass values show peaks around $60^{\circ} \mathrm{N}$ and between 40 and $20^{\circ} \mathrm{S}$, with declines towards both the equator and the poles. Biomass estimates between the equator and $40^{\circ} \mathrm{N}$ are below $5 \mu \mathrm{g} \mathrm{CL}^{-1}$. Biomass values show a clear seasonal cycle in the Northern Hemisphere, reaching a maximum in the summer months (June-July). In the Southern Hemisphere the seasonal cycle is less evident, possibly due to a greater proportion of low-latitude data. The original and gridded datasets can be downloaded from Pangaea (doi:10.1594/PANGAEA.785092).
\end{abstract}




\section{Introduction}

Marine plankton are the main driver for the global marine cycling of elements such as carbon, nitrogen and phosphorus, primarily through the process of carbon fixation and nutrient uptake during primary production and subsequent export of organic matter to the deep ocean. Modern marine ecosystem models seek to represent the functional diversity of marine plankton using the concept of plankton functional types (PFTs; Iglesias-Rodríguez, 2002; Le Quéré et al., 2005). PFTs are groups of plankton with defined biogeochemical functions, for example calcification, DMSproduction or nitrogen fixation. The inclusion of these groups in marine ecosystem models provides great potential for improving our understanding of marine processes (see for example Dutkiewicz et al., 2012; Marinov et al., 2010; Vogt et al., 2010; Manizza et al., 2010), but has also highlighted a need for extensive observational datasets for model parameterisation and validation (Hood et al., 2006; Le Quéré et al., 2005; Anderson, 2005).

The MARine Ecosystem DATa (MAREDAT) project (as part of the MARine Ecosystem Model Intercomparison Project - MAREMIP) seeks to compile global biomass data for PFTs commonly represented in marine ecosystem models: silicifiers, calcifiers (including coccolithophores, pteropods and foraminifera), DMS-producers, pico-phytoplankton, diazotrophs, bacteria, and three zooplankton sizeclasses (micro-, meso- and macrozooplankton). A summary of the findings for all groups is presented in Buitenhuis et al. (2013).

This paper presents a database of global coccolithophore biomass distributions compiled as part of the MAREDAT effort. The coccolithophores are a globally occurring group of calcifying phytoplankton of the class Prymnesiophyceae (Jordan et al., 2004; Winter and Siesser, 1994; Thierstein and Young, 2004). They are thought to play an important role in the global carbon cycle due to their contribution to primary production and export as well as through calcite production (Iglesias-Rodríguez, 2002; Hay, 2004; Jin et al., 2006), with blooms of over $100000 \mathrm{~km}^{2}$ observed in some ocean regions (Brown and Yoder, 1994; Holligan et al., 1993). The coccolithophores have received considerable attention in recent years due to their potential sensitivity to climate change and particularly ocean acidification (Doney et al., 2009). The decrease in carbonate saturation state in the oceans caused by rising atmospheric $\mathrm{CO}_{2}$ is generally expected to have negative effects on calcifying marine organisms due to the increasing energetic cost of calcification (Hofmann et al., 2010). There have, however, been mixed results from experimental and field studies of coccolithophores, with some showing a negative effect of ocean acidification (e.g. Beaufort et al., 2011; Riebesell and Zondervan, 2000) whereas others show no change or even increased calcification and production (Langer et al., 2006; Iglesias-Rodríguez et al., 2008). Changes in ocean temperature, stratification and nutri- ent supply are also expected to affect coccolithophore distributions, although again the direction of this change is unclear (Hood et al., 2006; Iglesias-Rodríguez, 2002). Given these uncertainties, it is more important than ever to understand the current distribution of coccolithophores in the global oceans.

Remote sensing approaches are frequently used to study the distribution of coccolithophore blooms (e.g. Smyth, 2004; Brown and Yoder, 1994; Iglesias-Rodríguez, 2002; Hirata et al., 2011). The reflective properties of the calcitebased coccoliths allow blooms to be observed in satellite images (Holligan et al., 1983), providing great potential for improving our understanding of coccolithophore distributions on a global scale. There are, however, several limitations to this approach. Firstly, satellite images pick up the optical properties of the calcite-based coccoliths themselves and do not distinguish between living cells and detached coccoliths (Tyrell and Merico, 2004). Secondly, satellite data are limited to waters within the optical depth of the satellite and provide no information as to the vertical structure of cells within the water column or cells occurring below this depth. Finally, more detailed taxonomic information cannot yet be obtained from satellite images. There is, therefore, a continuing need for in situ observations of coccolithophores in order to better understand their distribution, ecology and contribution to global plankton biomass.

This database compiles existing published and unpublished coccolithophore abundance data and provides standardised biomass estimates using species-specific conversion factors. We also provide a detailed discussion of our conversion methods and quality control procedures and discuss the uncertainties associated with the biomass values. Although this dataset was born from the needs of the modelling community, we anticipate that it will be of use to scientists from a range of fields including biological oceanography, marine ecology, biogeochemistry and remote sensing.

\section{Data}

\subsection{Origin of data}

Our data consists of abundance measurements obtained from several existing databases (NMFS-COPEPOD, BODC, OBIS, OCB DMO, Pangaea, WOD09, OOV) ${ }^{1}$, as well as published and unpublished data from a number of contributing authors (P. Ajani, H. Andruleit, J. Arístegui, L. Beaufort, M. Estrada, D. Karentz, E. Kopczyńska, R. Lee, T. Pritchard and C. Widdicombe). Table 1 summarises the origin of all

\footnotetext{
${ }^{1}$ NMFS-COPEPOD: National Marine and Fisheries Service The Coastal \& Oceanic Plankton Ecology, Production, \& Observation Database; BODC: British Oceanographic Data Centre; OBIS: the Ocean Biogeographic Information System; OCB DMO: Ocean Carbon and Biogeochemistry Coordination and Data Management Office; Pangaea: Data Publisher for Earth and Environmental Science; WOD09: World Ocean Database 2009; OOV: Observatoire Océanologique de Villefrance-sur-Mer.
} 
Table 1. List of data contributions, sorted in temporal order.

\begin{tabular}{|c|c|c|c|c|c|}
\hline Investigator/Institute & Year(s) & Region & Data points & Flagged & Reference \\
\hline Meteor & $1929-1930$ & N Atlantic & 66 & - & NMFS-COPEPOD \\
\hline Murmansk Marine Biological Institute, Russia & $1954-1973$ & Barents Sea & 267 & - & WOD09 \\
\hline H. Marshall & 1965 & NW Sargasso Sea & 32 & 32 & Marshall (1969) \\
\hline ORSTOM & 1965 & Tropical Pacific & 161 & - & WOD09 \\
\hline Instituto del Mar del Peru & $1966-2005$ & Peruvian coastal zone & 2668 & 92 & WOD09 \\
\hline NOAA/University of Alaska (OCSEAP) & $1969-1978$ & Gulf of Alaska & 293 & 265 & WOD09 \\
\hline J. Throndsen & 1970 & Tropical Pacific/Caribbean & 105 & - & NMFS-COPEPOD \\
\hline SAHFOS & $1970-1999$ & N Atlantic & 391 & - & WOD09 \\
\hline Institute of Biology of the Southern Seas, Ukraine & $1972-1990$ & Indian Ocean & 558 & - & NMFS-COPEPOD \\
\hline Tokyo University Ocean Research Institute, Japan & 1975 & W Pacific & 68 & - & WOD09 \\
\hline $\begin{array}{l}\text { National Institute for Environmental Studies, } \\
\text { Japan }\end{array}$ & $1976-1985$ & W Pacific & 120 & 44 & WOD09 \\
\hline NOAA & $1976-1977$ & Puget Sound, WA, US & 18 & - & WOD09 \\
\hline Japan Meteorological Agency & $1977-1986$ & W Pacific & 1963 & 29 & WOD09 \\
\hline Institute of Ocean Sciences, Sidney, Canada & 1979 & US Coast (Oregon) & 29 & - & WOD09 \\
\hline E. Baldina et al. & $1979-1986$ & Tropical Atlantic & 941 & - & NMFS-COPEPOD \\
\hline $\begin{array}{l}\text { Aomori Prefectural Fisheries Experimental } \\
\text { Station, Japan }\end{array}$ & 1980 & West Pacific & 2 & - & WOD09 \\
\hline TPFS & 1983 & West Pacific & 1 & - & WOD09 \\
\hline AtlantNIRO & $1984-1991$ & Atlantic & 365 & - & NMFS-COPEPOD \\
\hline M. Estrada & 1985 & Mediterranean Sea & 260 & - & $\begin{array}{l}\text { Estrada (1991), } \\
\text { Estrada (unpublished data) }\end{array}$ \\
\hline M. Estrada & 1985 & Weddell Sea & 126 & - & $\begin{array}{l}\text { Estrada and Delgado (1990), } \\
\text { Estrada (unpublished data) }\end{array}$ \\
\hline $\begin{array}{l}\text { Osaka Prefectural Fisheries Experimental Station, } \\
\text { Japan }\end{array}$ & 1985 & W Pacific & 8 & 8 & WOD09 \\
\hline P. Tett & 1988-1989 & North Sea & 50 & - & BODC \\
\hline D. Harbour & 1989 & North Atlantic & 33 & - & BODC \\
\hline B. Zeitzschel & 1989 & North Atlantic & 205 & 205 & Zeitzschel et al. (2002) \\
\hline D. Harbour & 1990 & North Atlantic & 68 & - & BODC \\
\hline D. Harbour & 1991 & North Atlantic & 78 & - & BODC \\
\hline AESOPS & 1992 & Southern Ocean & 31 & - & WOD09 \\
\hline G. Fryxell & 1992 & Equatorial Pacific & 186 & - & Fryxell (2003) \\
\hline K. Takahashi and H. Okada & 1992 & SE Indian Ocean & 114 & - & Takahashi and Okada (2000) \\
\hline M. Fiala & 1992-1995 & Southern Ocean & 73 & - & OOV \\
\hline E. Ramos & 1992-2005 & Peruvian Coastal Zone & 229 & - & Ramos (2006) \\
\hline C. Widdicombe & 1992-2008 & English Channel & 625 & - & Widdicombe et al. (2010) \\
\hline H. Andruleit & 1993 & Arabian Sea & 71 & - & Andruleit (2003) \\
\hline R. Uncles & $1993-1995$ & North Sea & 20 & - & BODC \\
\hline P. Wassmann and T. Ratkova & $1993-2003$ & Arctic/Sub-Arctic & 108 & - & Ratkova (2012) \\
\hline D. Harbour & 1994 & Arabian Sea & 65 & - & BODC \\
\hline OMEX I project members; P. Wassmann & 1994 & NE Atlantic & 186 & - & $\begin{array}{l}\text { Omex I project members and } \\
\text { Wassmann (2004) }\end{array}$ \\
\hline C. Grados & 1995 & Peruvian Coastal Zone & 12 & - & Grados et al. (2007) \\
\hline R. Schiebel & $1995-1997$ & Arabian Sea & 49 & - & Schiebel $(2004 a, b)$ \\
\hline $\begin{array}{l}\text { J. Aiken, T. Bale, P. Holligan, A. Poulton } \\
\text { and D. Robins }\end{array}$ & $1995-2000$ & Atlantic & 408 & - & BODC \\
\hline G. Tarran & 1996 & North Atlantic & 199 & - & BODC \\
\hline P. Ajani, R. Lee and T. Pritchard & 1997-1998 & SE Australia & 45 & 45 & Ajani et al. (2001) \\
\hline H. Andruleit & 1999 & E Indian Ocean & 45 & - & Andruleit (2007) \\
\hline K. Pagou and G. Assimakopoulou & 1999-2000 & Aegean Sea & 52 & - & $\begin{array}{l}\text { Pagou and Assimakopoulou } \\
(2008)\end{array}$ \\
\hline H. Andruleit & 2000 & Arabian Sea & 22 & - & Andruleit (2005) \\
\hline D. Karentz & 2000 & E Pacific & 7 & - & Karentz (unpublished data) \\
\hline E. Kopczyńska & 2001 & Southern Ocean & 13 & - & Kopczyńska et al. (2007) \\
\hline H. Andruleit & $2001-2002$ & E Pacific & 49 & - & Andruleit (unpublished data) \\
\hline J. Arístegui & 2003-2004 & N Atlantic & 152 & - & Arístegui (unpublished data) \\
\hline P. Assmy & 2004 & Southern Ocean & 28 & - & Assmy (2007) \\
\hline L. Beaufort & 2004 & Pacific & 99 & - & Beaufort (unpublished data) \\
\hline R. Mohan & 2004 & Southern Ocean & 131 & - & Mohan et al. (2008) \\
\hline M. Silver & 2004 & Hawaii & 13 & - & Silver (2009) \\
\hline
\end{tabular}


datasets, sorted in temporal order. The database contains 58384 data points when all counts of individual taxa are considered separately, which equates to 11503 samples of total coccolithophore abundance collected from 6741 depthresolved stations. Abundance data were standardised to units of cells per litre, and ancillary data such as temperature, salinity, chlorophyll and nutrients were retained where available.

\subsection{Biomass conversion}

To convert the abundance data (cell counts per unit volume) to biomass estimates (expressed as the concentration of organic carbon per unit water volume), we first needed to multiply the abundance data by the average biovolume for each species, and then multiplied the resulting biovolume concentration with the average organic carbon content per biovolume.

We determined cell biovolumes for each of the taxonomic groups reported in the database based on an extensive literature survey. Coccolithophore taxonomy has been subject to numerous revisions over the time span of the dataset, making it challenging to match historical data to current species names and descriptions. For consistency, data entries were matched to currently accepted species names following the taxonomic scheme of Jordan et al. (2004) wherever possible. Where full taxonomic information was not provided, data were matched to the lowest taxonomic group possible. Data that could not be assigned to a particular taxonomic group were categorised as unidentified coccolithophores. We identified a total of 195 taxonomic groups for this dataset (Table A3), ranging from identifications at the sub-species to the family level. Morphotype information is reported for Emiliania huxleyi in only one dataset, and we have therefore chosen to use a single biomass conversion factor for all occurrences of this species. Additionally, 2258 samples consisted of combined counts of coccolithophores without further size or taxonomic information, and 1988 samples contained at least some counts of unidentified or partially identified coccolithophores. For our biomass conversions, we began by converting only cell counts for which full species or sub-species identifications were provided. Each species/subspecies was assigned an idealised shape (e.g. sphere, prolate sphere, cone) based on the work of Hillebrand et al. (1999) and Sun (2003) as well as species descriptions in the literature. We then estimated cell dimensions (e.g. diameter, length, width) for each taxonomic group in order to calculate cell biovolumes (units: $\mu \mathrm{m}^{3}$ ).

Cytoplasm dimensions have been published for very few coccolithophore species, with species descriptions usually providing the more easily observed coccosphere dimensions only. Observations of 16 species of coccolithophore from laboratory and field studies show cytoplasm diameter varying from 30 to $90 \%$ of the total coccosphere diameter, depending on the species and level of calcification (Table 2); naked coccolithophores have also been observed for some species, although they are relatively rare in field samples (Frada et al., 2012). While these 16 species represent only a small fraction $(10 \%)$ of the species represented in the database, they include some of the more dominant coccolithophores in terms of both abundance and frequency of observation: these 16 species together account for an average of $75 \pm 32 \%$ of coccolithophore abundance per sample (median $=92 \%$ ), and we therefore consider them to be reasonably representative for the purposes of estimating coccolithophore biomass.

Given the lack of data and the lack of consistency among the few available cytoplasm measurements, we chose to estimate coccolithophore biovolumes by assuming cytoplasm dimensions to be $60 \%$ of the mean coccosphere dimensions for all species - this value represents the midpoint of observed ratios of cytoplasm to total coccosphere diameter. These calculations can be expected to overestimate organic biomass for species with a higher ratio of coccosphere to cytoplasm volume, and underestimate biomass for species with a lower ratio. Biovolumes are calculated based on the mid-point of coccosphere dimensions. Uncertainty ranges are provided using biovolumes and biomasses calculated from $0.6 \times \mathrm{min}$ imum coccosphere dimensions and $0.6 \times$ maximum coccosphere dimensions.

The range of coccosphere dimensions (e.g. diameter, length, width) for each species or sub-species in the database was determined based on a literature survey (Table A3). For some datapoints, coccosphere dimensions were provided alongside abundance data. In these cases the provided measurements were used in preference to our literature-based values. Biovolume estimates were then further converted to carbon biomass (units: $\mu \mathrm{gCL}^{-1}$ ) using the prymnesiophytespecific conversion factor developed by Menden-Deuer and Lessard (2000). Biovolume and biomass values based on the mid-point are hereafter referred to as "mean" biovolume and biomass. We assess the likely over- or under-estimation of our mean biomass estimates for different species of coccolithophore through a comparison with direct biomass measurements as well as biomass values calculated from measured cytoplasm dimensions for 16 species (Table 2).

For 23 species only a single set of dimensions or a single biovolume value was reported in the literature. In these cases, we have assumed the reported values to be the mean estimates. Minimum and maximum biovolume values were estimated for these species based on the ratios of minimum and maximum biovolume to mean biovolume observed for all other species in the database. These ratios were found to be 0.5 ( \pm standard deviation of 0.2 ) for minimum biovolume/mean biovolume, and $2.1( \pm 0.8)$ for maximum biovolume/mean biovolume. For cell counts with identifications only to the level of genus or family, or for combined counts of multiple species, we calculate minimum and maximum biomass values per cell based on the absolute minimum and maximum of all species reported for that taxonomic group. Mean biomass values per cell were calculated by taking the 
Table 2. Comparison of coccolithophore biomass estimates from coccosphere dimensions (assuming cytoplasm diameter $=0.6 \times$ coccosphere diameter) with biomass estimates from observed cytoplasm diameters for 16 species. Cytoplasm dimensions are from Stoll et al. (2002) as well as previously unpublished measurements from the datasets presented in Franklin et al. (2009) and Poulton et al. (2010).

\begin{tabular}{|c|c|c|c|c|c|}
\hline \multirow[t]{2}{*}{ Species } & \multicolumn{3}{|c|}{ Coccosphere } & \multicolumn{2}{|c|}{ Cytoplasm } \\
\hline & $\begin{array}{l}\text { Diameter } \\
\qquad(\mu \mathrm{m})\end{array}$ & $\begin{array}{l}\text { Estimated } \\
\text { cell diameter } \\
\qquad(\mu \mathrm{m})\end{array}$ & $\begin{array}{l}\text { Biomass estimate } \\
\left.\text { (pgCcell }{ }^{-1}\right)\end{array}$ & $\begin{array}{c}\text { Diameter } \\
\text { (corresponding coccosphere) } \\
(\mu \mathrm{m})\end{array}$ & $\begin{array}{l}\text { Biomass estimate } \\
\left.\text { (pgCcell }{ }^{-1}\right)\end{array}$ \\
\hline Algirosphaera robusta & $6.5-16$ & 6.75 & 22 & $5.29(16.9)$ & 11.4 \\
\hline Calcidiscus leptoporus & $5-28$ & 9.9 & 61.8 & $9.6-11.3(16.25-30.75)$ & $57.2-89.1$ \\
\hline Calcidiscus quadriperforatus & $10-15$ & 7.5 & 29.2 & $10.2(32.5)$ & 66.4 \\
\hline Coccolithus pelagicus & $8-22$ & 9.0 & 47.8 & $14.1(16.3)$ & 160.6 \\
\hline Discosphaera tubifera & $4.5-14$ & 6.0 & 16.0 & $4.7(15.0)$ & 8.3 \\
\hline Emiliania huxleyi & $3.5-15$ & 5.6 & 13.0 & $3.4-3.5(5.4-11.0)$ & $3.5-3.7$ \\
\hline Florisphaera profunda & $4-12$ & 4.8 & 8.8 & $3.9(12.4)$ & 4.9 \\
\hline Gephyrocapsa oceanica & $5-15$ & 6.0 & 16.0 & $5.0(16.1)$ & 9.9 \\
\hline Oolithotus antillarum & $10-13$ & 6.9 & 23.3 & $4.7(15.1)$ & 8.3 \\
\hline Oolithotus fragilis & $4-30$ & 10.2 & 66.9 & $13.8(27.5)$ & 149.8 \\
\hline Rhabdosphaera clavigera & $7.9-12$ & 6.0 & 15.8 & $6.3(20.0)$ & 18.2 \\
\hline Syracosphaera tumularis & $10-20$ & 9.0 & 47.8 & $15.7(50.3)$ & 215.2 \\
\hline Umbellosphaera irregularis & $10-15$ & 7.5 & 29.2 & $6.3(20.0)$ & 17.9 \\
\hline Umbellosphaera tenuis & $9.2-16$ & 7.6 & 29.8 & $5.7(18.3)$ & 14.1 \\
\hline Umbilicosphaera sibogae & $8.5-43$ & 15.5 & 205.1 & $7.1-30(25-60)$ & $25.3-1227.9$ \\
\hline Umbilicosphaera foliosa & $10-18$ & 8.4 & 39.6 & $8.8-9.4(12.6-30)$ & $44.3-53.5$ \\
\hline
\end{tabular}

mean of all reported biomass values for species within the taxonomic group. Taking the mean of the biomass values avoided weighting mean biomass values towards a single large species. For some genera, however, insufficient specieslevel data were available to calculate biomass using this approach. In these cases we were able to obtain a range of coccosphere dimensions from the literature, and calculated biovolumes and biomasses based on the mid-point of these values as detailed above for the species-specific cell counts.

For cell counts of unidentified coccolithophores, we have chosen to use a spherical coccosphere with diameter of $10 \mu \mathrm{m}$ (cell diameter of $6 \mu \mathrm{m}$ ) to calculate our mean biovolume and biomass estimates. This value was selected based on the diameters of species most commonly occurring in the database. The large uncertainty associated with this value is taken into account by providing minimum and maximum biovolume and biomass estimates based on the absolute minimum and maximum values across all species in the database. Following the biomass conversions, data were compiled to total coccolithophore biomass per sample for the purposes of further analyses. Further taxonomic information is reported in the attached dataset (doi:10.1594/PANGAEA.785092) and coccolithophore biodiversity patterns will be discussed in O'Brien et al. (2013).

\subsection{Quality control}

Our quality control procedure flagged data based on a number of criteria, with flag values (1-4) provided in the data table. Flag 1 was applied to 33 samples that included obser- vations of the species Thoracosphaera heimii - this species was originally thought to be a coccolithophore, but further investigations have shown it to be a calcified dinoflagellate cyst (Tangen et al., 1982). Flag 2 was applied to 205 samples for which only biomass values were provided, without corresponding cell counts; and flag 3 is applied to 482 samples with integrated water column values rather than discrete depth measurements, or to samples for which no depth information was provided. Flag 4 was assigned to outliers identified by the statistical analyses to be outlined below.

For the next stage of the quality control process, we removed samples with flags 2 and 3 and corrected samples with flag 1 to remove counts of T. heimii. For the remaining 9194 non-zero samples, we used Chauvenet's criterion to identify statistical outliers in the log-normalized biomass data (Buitenhuis et al., 2013; Glover et al., 2011). Based on this analysis, we identified one sample with a biomass value with probability of deviation from the mean greater than $1 / 2 n$, with $n=8997$ being the number of non-zero samples (two-sided $z$ score: $|z c|=4.03$ ). This sample is denoted by a flag value of 4 .

An additional flag column denotes the quantification method used for determining coccolithophore abundance. Of the 9193 non-zero samples included in the database, 4209 are known to have been analysed using light microscopy, 500 using SEM and 197 with flow cytometry. For the remaining 4287 the method is unknown. Coccolithophore counts from SEM are consistently higher than those obtained using light microscopy due to the better identification of smaller and more fragile species. For example, Bollmann 


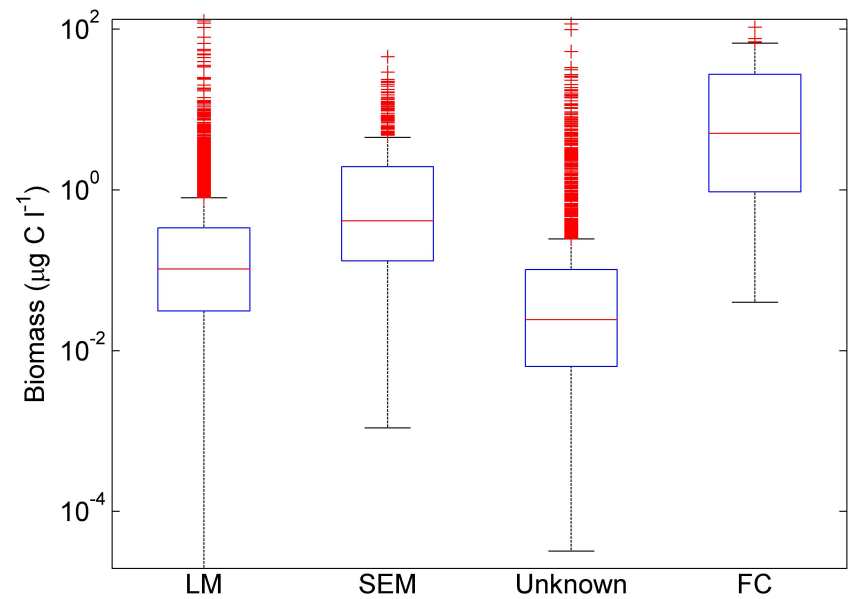

Figure 1. Boxplots depicting distributions of non-zero biomass estimates for different quantification methods: light microscopy (LM), scanning electron microscopy (SEM), unknown method and flow cytometry (FC). Horizontal lines depict the median, boxes depict the interquartile range (25th to 75th percentiles) and points marked beyond the whiskers of the plot are outliers (points falling greater than 1.5 times the interquartile range below the 25 th percentile or above the 75 th percentile).

et al. (2002) found that species such as syracosphaerids, small reticulofenestrids, small gephyrocapsids and holococcolithophores are likely to be missed in light microscopy analyses. Cell density has been shown to differ up to $23 \%$ between the two methods when analysing samples with large numbers of small species such as E. huxleyi, Gephyrocapsa ericsonii and G. protohuxleyi.

We have made a statistical comparison of abundance and biomass values to determine whether a systematic bias can be associated with the enumeration method for samples in our database (Table 3, Fig. 1). Our comparison of coccolithophore abundance and biomass shows greater differences between methods than would be expected from previous comparisons of enumeration methods, but we suggest that these differences are likely to be at least partially explained by real differences in coccolithophore abundance and community composition. For example, we expect that SEM is more likely to be used for samples with a known portion of small coccolithophores which are difficult to identify or enumerate using light microscopy alone. Although median biomass from SEM studies is higher by a factor of four than the median for light microscopy studies, the highest values reported in the dataset are from light microscopy studies. Since the quantification method is unknown for nearly $50 \%$ of samples, we have chosen to retain SEM data in the gridded dataset and all analyses, though users may access a subset of this data from the raw file. In contrast, we have excluded 199 datapoints collected using flow cytometry from the gridded dataset. These values are significantly higher again than those collected using either SEM or light microscopy.

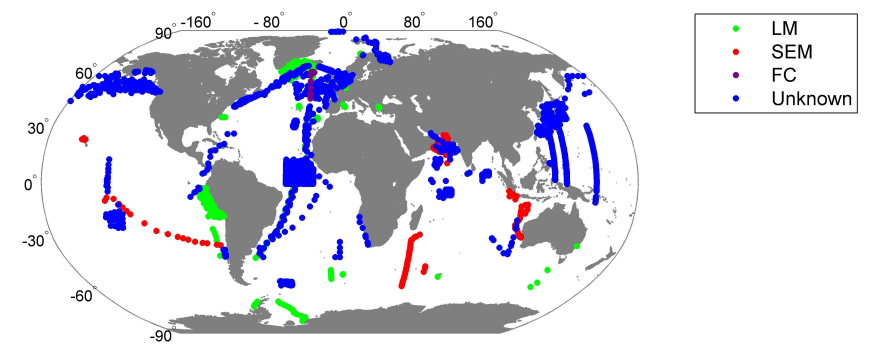

Figure 2. Global distribution of coccolithophore observations included in the dataset. Marker colour denotes the quantification method used: light microscopy (green), SEM (red), flow cytometry (cyan) and unknown (blue)

Table 3. Biomass estimates $\left(\mu \mathrm{gCL}^{-1}\right)$ for four analysis methods: light microscopy (LM), scanning electron microscopy (SEM), flow cytometry (FC) and unreported analysis method (unknown). All values are reported for non-zero biomass estimates only.

\begin{tabular}{lrrrrr}
\hline Method & $n$ & Median & Mean & St. Dev. & Max \\
\hline LM & 4209 & 0.10 & 0.72 & 4.38 & 126.5 \\
SEM & 500 & 0.41 & 2.25 & 4.41 & 45.2 \\
FC & 197 & 5.04 & 14.66 & 18.29 & 105.5 \\
Unknown & 4287 & 0.024 & 0.39 & 2.96 & 116.0 \\
\hline
\end{tabular}

Based on our full quality control procedure we removed a total of 888 flagged samples for the purposes of our analyses, and a further 32 samples were corrected to remove the contribution of $T$. heimii to total coccolithophore biomass (note: one sample contained data for T. heimii only). All data are included in the published raw dataset in the event that a user has different requirements for the quality control procedure, while the gridded dataset contains the unflagged datapoints only.

An additional column in the raw dataset denotes the taxonomic level to which coccolithophores are identified, as this has a major influence on the level of uncertainty associated with our biomass calculations. Coccolithophores identified to species level are denoted by the flag value 0 , those identified to genus or family level as flag value 1 , and unidentified coccolithophores as flag value 3 . If coccosphere dimensions are known, cells identified to genus or family level receive flag value 2 , and unidentified coccolithophores receive flag value 4. All samples of unidentified or partially identified coccolithophores have been included in our analyses and in the gridded file.

Several datasets report biomass values in addition to abundance data. While we have chosen to use our own conversion methods for consistency, it is likely that the original biomass values are based on more accurate estimates of cell size. All original biomass values are included in the submitted database and can be substituted for our estimates if desired. 
(a)

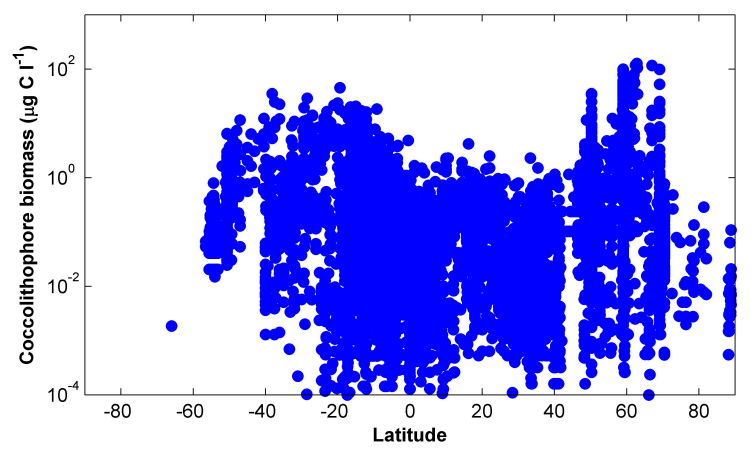

(b)

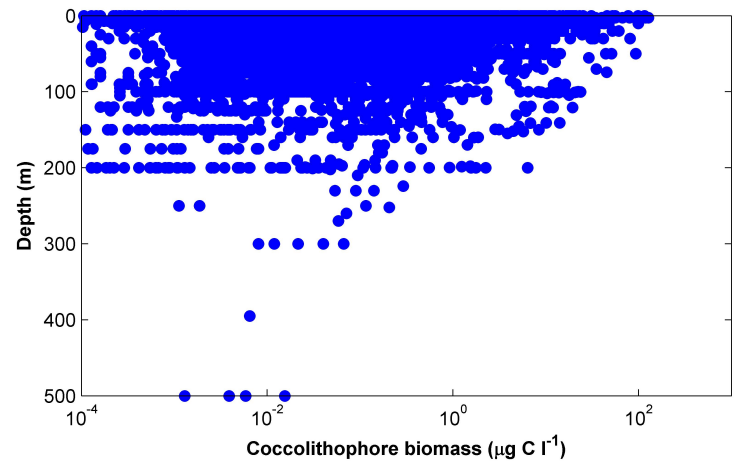

Figure 3. Distribution of coccolithophore biomass $\left(\mu \mathrm{gCL}^{-1}\right)(\mathbf{a})$ as a function of latitude and (b) as a function of depth.

\section{Results}

Excluding flagged data, the database contains coccolithophore biomass observations for 11503 samples, collected from 6741 depth-resolved stations (Fig. 2). Highest coccolithophore abundance is $9.8 \times 10^{6}$ cells $\mathrm{L}^{-1}$. 2507 , or $21.8 \%$ of samples, were found to be zero values. These data were retained in the dataset, since confirmed zero values hold valuable information for the study of plankton distributions. There is, however, inconsistency in the reporting of zero values in plankton datasets: often abundance data are reported only for a limited range of target groups that are expected to be present. There is also likely to be a bias due to sampling focusing on areas where coccolithophores are expected to occur. Values reported in the subsequent sections are therefore calculated based on non-zero data only. Where zerodatapoints are included, this value follows in parentheses. Arithmetic mean values are reported plus or minus one standard deviation. We also provide median biomass values, as these are less influenced by high values and provide a better representation of the central tendency of the data.

\subsection{Spatial and temporal coverage}

The database includes non-zero coccolithophore observations from the surface to a depth of $500 \mathrm{~m}$ (Fig. 3b, with $83.9 \%$ of observations ( $84.1 \%$ with zero values included) from the upper $50 \mathrm{~m}$ and $61.5 \%(63.3 \%)$ from the upper $10 \mathrm{~m}$ of the water column. Mean depth is $27.0( \pm 40.5) \mathrm{m}$ and median depth is $10.0 \mathrm{~m}$. Data are reported from all ocean basins, with $54.4 \%$ of samples $(58.9 \%$ with zero values included) from the Northern Hemisphere and $45.4 \%$ (40.9\%) from the Southern Hemisphere (Table 4). 31.6\% of nonzero data are from the Atlantic Ocean, $40.2 \%$ from the Pacific Ocean and $10.4 \%$ from the Indian Ocean. Despite the high number of observations reported from the Pacific compared to the Atlantic, the spatial coverage of this ocean basin is relatively poor, with many observations limited to intensively studied regions in Peruvian and Japanese coastal waters. $9.9 \%$ of non-zero observations are from the polar re-

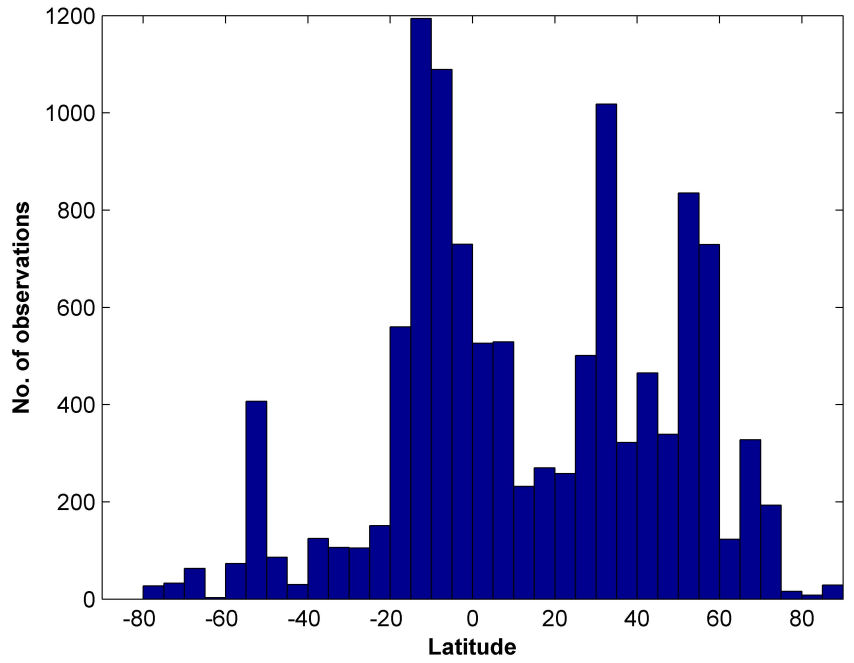

Figure 4. Frequency distribution of coccolithophore observations as a function of latitude for the period 1929-2008.

gions, with $5.1 \%$ from the Southern Ocean and $4.8 \%$ from Arctic waters. Coccolithophores are reported to be present in only one sample below $60^{\circ} \mathrm{S}$ (Table 5, Fig. 4). In contrast, the database contains non-zero observations of coccolithophores in Arctic waters up to a maximum of $88.92^{\circ} \mathrm{N} .46 .3 \%$ of data are from tropical waters between $20^{\circ} \mathrm{S}$ and $20^{\circ} \mathrm{N}$.

Data are reported from the years 1929 to 2008 (Fig. 5). A total of 66 non-zero observations are reported for 19291930, with no further observations until $1954.78 .7 \%$ of observations were collected between 1980 and 2008, and $51.8 \%$ between 1990 and 2008. Data are reported from all months of the year in both hemispheres, although relatively few data were collected during the winter months $(13.6 \%$ of all NH data, $15.6 \%$ of SH data, Table 4). Northern Hemisphere data are strongly biased towards summer observations (38.4\% of all data). 
Table 4. Seasonal distribution of abundance data for the Northern and Southern Hemisphere. Number of data points for each month. All: all data, non-zero: data with non-zero carbon biomass.

\begin{tabular}{lrrrrrr}
\hline Month & $\begin{array}{r}\text { Globe } \\
\text { all }\end{array}$ & $\begin{array}{r}\text { Globe } \\
\text { non-zero }\end{array}$ & $\begin{array}{r}\text { NH } \\
\text { all }\end{array}$ & $\begin{array}{r}\text { NH } \\
\text { non-zero }\end{array}$ & $\begin{array}{r}\text { SH } \\
\text { all }\end{array}$ & $\begin{array}{r}\text { SH } \\
\text { non-zero }\end{array}$ \\
\hline Jan & 737 & 367 & 489 & 177 & 247 & 189 \\
Feb & 1271 & 922 & 389 & 260 & 881 & 662 \\
Mar & 872 & 729 & 489 & 367 & 383 & 362 \\
Apr & 942 & 793 & 433 & 317 & 500 & 467 \\
May & 1095 & 935 & 634 & 534 & 461 & 401 \\
Jun & 944 & 607 & 694 & 394 & 246 & 213 \\
Jul & 1203 & 859 & 1056 & 734 & 146 & 125 \\
Aug & 1053 & 942 & 697 & 607 & 356 & 335 \\
Sep & 111 & 1005 & 810 & 728 & 290 & 266 \\
Oct & 1304 & 975 & 699 & 441 & 605 & 534 \\
Nov & 752 & 671 & 245 & 196 & 507 & 475 \\
Dec & 219 & 191 & 59 & 50 & 160 & 141 \\
\hline Spring & - & - & 1556 & 1218 & 1402 & 1275 \\
Summer & - & - & 2447 & 1735 & 1288 & 992 \\
Autumn & - & - & 1754 & 1365 & 1344 & 1230 \\
Winter & - & - & 937 & 487 & 748 & 673 \\
\hline Total & 11503 & 8996 & 6694 & 4805 & 4782 & 4170 \\
\hline
\end{tabular}

\subsection{Biomass distribution}

\subsubsection{Geographical distribution}

Coccolithophore biomass values range from $2.0 \times 10^{-5}$ to $127.2 \mu \mathrm{gCL}^{-1}$. The global mean is $0.88 \mu \mathrm{gCL}^{-1} \pm$ $4.8 \mu \mathrm{gCL}{ }^{-1}$ and median biomass is $0.072 \mu \mathrm{gCL}^{-1}$. Highest median biomass values were recorded in the Southern Hemisphere between 40 and $50^{\circ} \mathrm{S}(0.77$, Figs. 3, 6, Table 5), and in the Northern Hemisphere between 50 and $60^{\circ} \mathrm{N}$. Maximum biomass values show peaks around $60^{\circ} \mathrm{N}$ and between 40 and $20^{\circ} \mathrm{S}$, with declines towards both the equator and the poles. Biomass estimates between the equator and $40^{\circ} \mathrm{N}$ are below $5 \mu \mathrm{gCL}{ }^{-1}$. The highest biomass estimate of $127.2 \mu \mathrm{gCL}^{-1}$ is for a sample off the Icelandic coast $\left(62.8^{\circ} \mathrm{N}, 20.0^{\circ} \mathrm{W}\right)$.

Strong differences can be observed between the Atlantic and Pacific Ocean, with Atlantic biomass values reaching 127.2 $\mu \mathrm{g} \mathrm{CL}^{-1}$ (mean $1.7 \pm 7.5$, median $0.12 \mu \mathrm{g} \mathrm{CL}^{-1}$ ) compared to just $20.0 \mu \mathrm{gCL}^{-1}$ in the Pacific (mean $0.3 \pm 0.9$, median $0.04 \mu \mathrm{gCL}^{-1}$ ). The relatively poor spatio-temporal coverage of Pacific Ocean observations, however, may contribute to this discrepancy. Indian Ocean biomass values reach a maximum of $45.2 \mu \mathrm{gCL}^{-1}$, with a mean of $1.1 \pm 3.4$ and median of $0.03 \mu \mathrm{gCL} \mathrm{CL}^{-1}$.

In the Southern Ocean, the maximum biomass value reported is $6.5 \mu \mathrm{gCL}^{-1}$, mean biomass is $0.19 \pm 0.58 \mu \mathrm{gCL}^{-1}$ and median biomass is $0.04 \mu \mathrm{gCL}^{-1}$. Higher values are recorded in the Arctic Ocean, with a maximum of $98.9 \mu \mathrm{gCL} \mathrm{CL}^{-1}$, mean of $0.78 \pm 5.7 \mu \mathrm{gCL}^{-1}$ and median of $0.05 \mu \mathrm{gCL}^{-1}$.

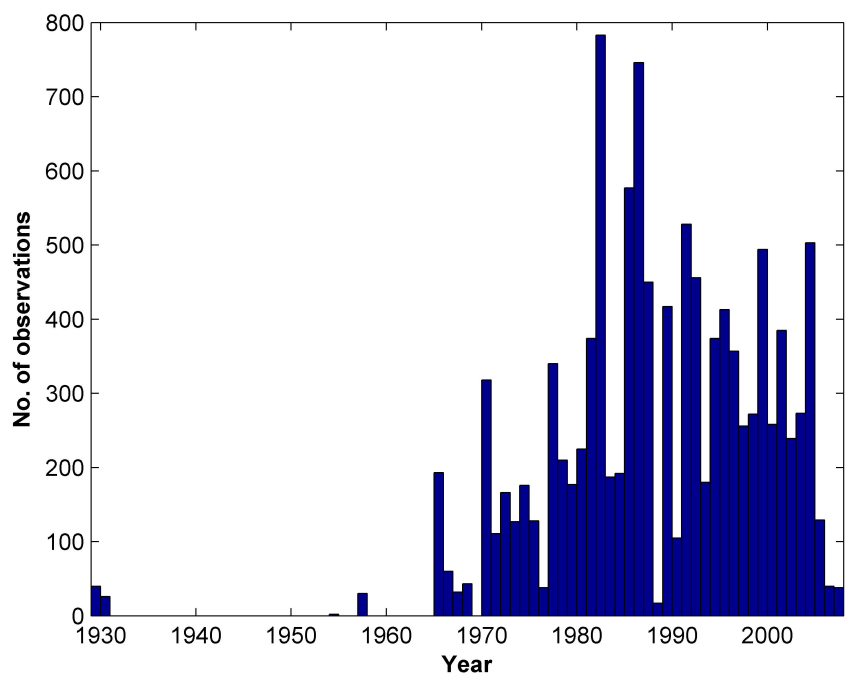

Figure 5. Frequency distribution of coccolithophore observations by year, for the period 1929-2008.

\subsubsection{Depth distribution}

Highest biomass values are reported in surface waters and decline with depth (Figs. 3b, 6), although biomass values of up to $23 \mu \mathrm{gCL} \mathrm{CL}^{-1}$ are still reported at $100 \mathrm{~m}$ depth. Mean biomass for the surface layer $(0-10 \mathrm{~m})$ is $0.9 \pm 5.2 \mu \mathrm{gCL}-1$ and median biomass is $0.09 \mu \mathrm{gCL}^{-1}$. Biomass values below $200 \mathrm{~m}$ reach a maximum of $0.01 \mu \mathrm{gCL}-1$. The deepest observations of coccolithophores are at $500 \mathrm{~m}$ depth, with biomasses reaching a maximum of just $0.004 \mu \mathrm{gCL}^{-1}$.

\subsubsection{Seasonal distribution}

The data show a clear seasonal cycle in the Northern Hemisphere, with biomass values reaching just $1.1 \mu \mathrm{gCL}^{-1}$ in December and over $100 \mu \mathrm{gCL}^{-1}$ in the summer months (JuneJuly, Fig. 7). In the Southern Hemisphere the seasonal cycle is less evident, possibly due to the greater contribution of data from low latitudes where seasonal changes are less pronounced.

\subsubsection{Uncertainty}

The expected uncertainty associated with our conversions of cell abundance to carbon biomass due to varying cell size is depicted in Fig. 8. Biomass estimates are best constrained where detailed taxonomic information is available, and for samples containing species for which a limited size range has been reported. Very high uncertainty (range of biomass values greater than $5000 \%$ of the mean biomass) is associated with counts of unidentified coccolithophores. This is to be expected given the large range of sizes reported for the approximately 200 known coccolithophore species (see Appendix Table A3). 

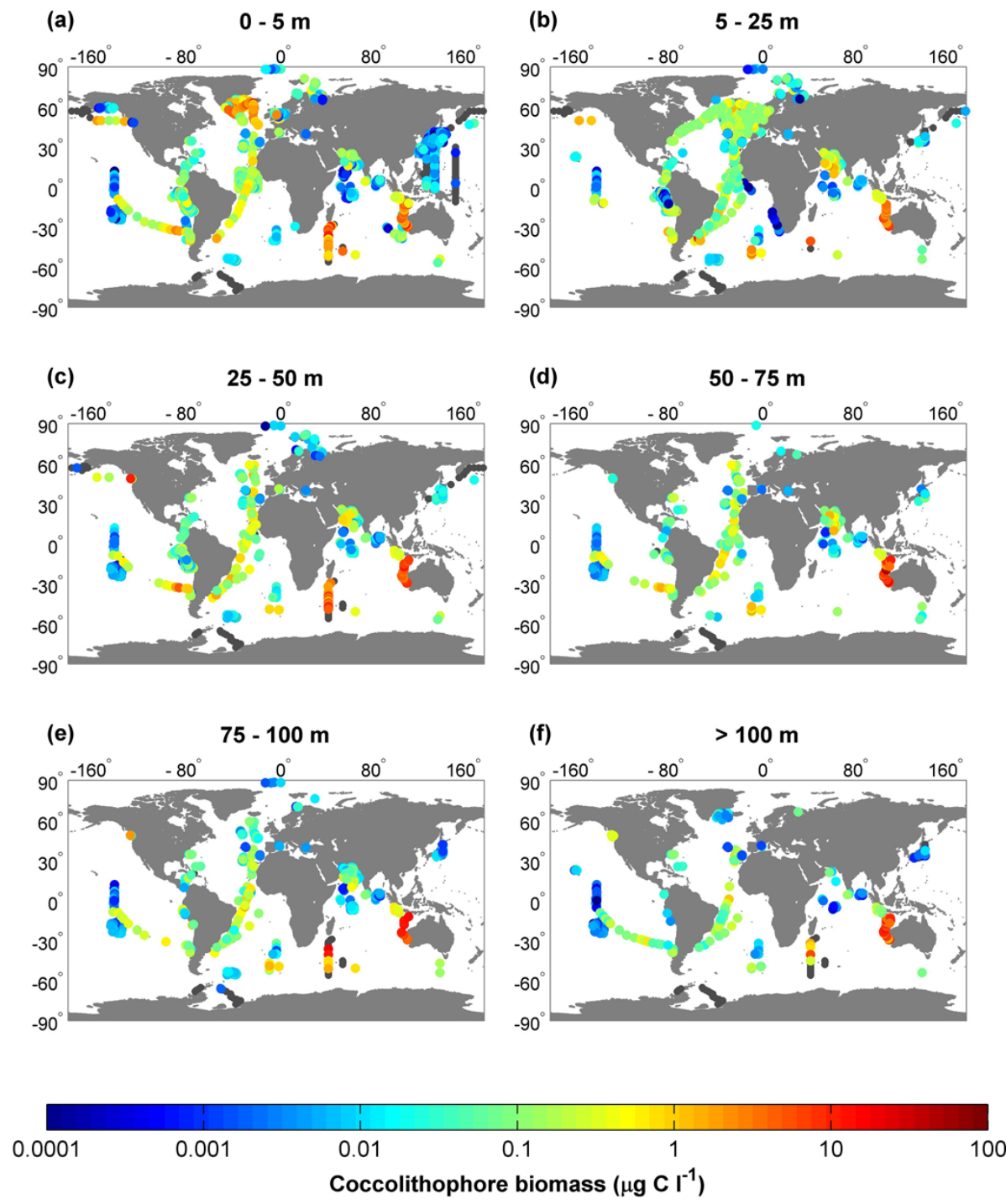

Figure 6. Mean coccolithophore carbon biomass $\left(\mu \mathrm{gCL}^{-1}\right)$ for six depth bands (a) 0-5 m (b) 5-25 m (c) 25-50 m (d) 50-75 m (e) 75-100 m and (f) $>100 \mathrm{~m}$ depth.
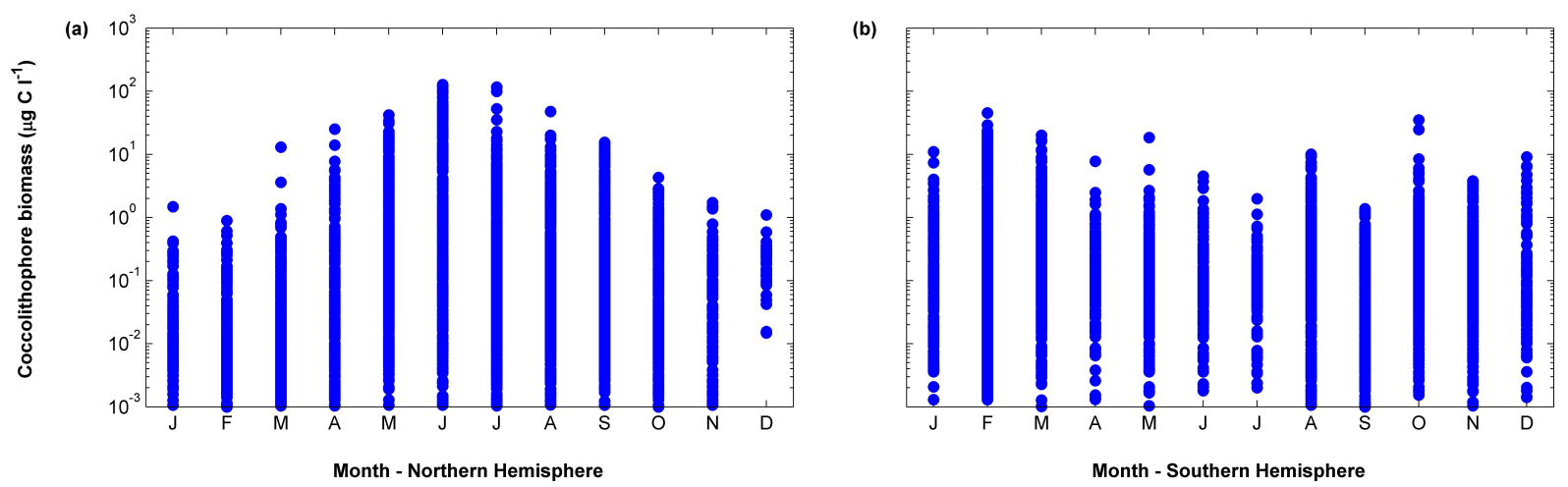

Figure 7. Seasonal distribution of coccolithophore biomass data for (a) Northern Hemisphere and (b) Southern Hemisphere. 
Table 5. Latitudinal distribution of quality-controlled data in ten degree latitudinal bands $\left(-90\right.$ to $\left.90^{\circ}\right)$. All data: total number of data points; non-zero data: number of non-zero biomass values; mean, standard deviation, median and maximum biomass values calculated from non-zero data only.

\begin{tabular}{rrrrrrr}
\hline Latitudinal band & All data & Non-zero data & Mean & S.D. & Median & Max \\
\hline$-90--80^{\circ}$ & 0 & 0 & - & - & - & - \\
$-80--70^{\circ}$ & 60 & 0 & - & - & - & - \\
$-70--60^{\circ}$ & 66 & 1 & 0.002 & - & 0.002 & 0.002 \\
$-60--50^{\circ}$ & 480 & 456 & 0.2 & 0.5 & 0.04 & 6.5 \\
$-50--40^{\circ}$ & 116 & 77 & 1.8 & 2.4 & 0.77 & 12.3 \\
$-40--30^{\circ}$ & 231 & 207 & 1.1 & 3.7 & 0.19 & 35.1 \\
$-30--20^{\circ}$ & 256 & 247 & 2.0 & 4.0 & 0.16 & 29.1 \\
$-20--10^{\circ}$ & 1754 & 1467 & 0.7 & 2.2 & 0.09 & 45.2 \\
$-10-0^{\circ}$ & 1819 & 1715 & 0.2 & 0.7 & 0.05 & 18.4 \\
$0-10^{\circ}$ & 1055 & 860 & 0.1 & 0.2 & 0.03 & 2.3 \\
$10-20^{\circ}$ & 502 & 315 & 0.2 & 0.4 & 0.09 & 4.2 \\
$20-30^{\circ}$ & 759 & 420 & 0.1 & 0.2 & 0.02 & 2.5 \\
$30-40^{\circ}$ & 1340 & 773 & 0.1 & 0.1 & 0.01 & 2.3 \\
$40-50^{\circ}$ & 804 & 505 & 0.3 & 0.7 & 0.10 & 11.5 \\
$50-60^{\circ}$ & 1564 & 1319 & 2.7 & 7.8 & 0.32 & 99.3 \\
$60-70^{\circ}$ & 451 & 451 & 3.7 & 14.7 & 0.10 & 127.2 \\
$70-80^{\circ}$ & 209 & 146 & 0.1 & 0.1 & 0.05 & 0.8 \\
$80-90^{\circ}$ & 37 & 37 & 0.02 & 0.05 & 0.007 & 0.3 \\
\hline
\end{tabular}

An additional source of uncertainty, however, is the estimation of cell biovolumes from coccosphere dimensions, and is more difficult to quantify. A comparison of our biomass estimates based on coccosphere dimensions with estimates from available cytoplasm dimensions suggests that we may be underestimating coccolithophore biomass values by a factor of up to 5 for some species (Table 2). It is worth noting, however, that the cytoplasm dimensions considered here are based on either culture specimens (Stoll et al., 2002) or a small number of field samples from the Icelandic Basin (Poulton et al., 2010) and the Mauritanian Upwelling (Franklin et al., 2009). For one of the best-studied species, E. huxleyi, our mean biomass estimate of $13 \mathrm{pg} \mathrm{C}$ cell $^{-1}$ falls within the range of published carbon measurements of 7.8 to $27.9 \mathrm{pg} \mathrm{C} \mathrm{cell}^{-1}$ (Fernandez et al., 1993; van Bleijswijk et al., 1994; Verity et al., 1992), while our estimates from the cytoplasm measurements in Table 2 show much lower values of 3.5-3.7 $\mathrm{pgC} \mathrm{cell}^{-1}$.

\section{Discussion}

There are many sources of uncertainty associated with our calculations. We have attempted to quantify the uncertainty associated with variable cell dimensions by providing minimum and maximum biomass values for each datapoint, but this does not represent the full range of uncertainty associated with our biomass values.

The estimation of cell biovolumes from coccosphere dimensions is likely to result in additional errors which are at present difficult to quantify. A more accurate estima- tion of coccolithophore biomass will only be possible with improved understanding of coccolithophore cytoplasm dimensions (e.g. Stoll et al., 2002), and we highlight this as a key data requirement for improved estimates of coccolithophore biomass from abundance data. While the routine measurement of coccolithophore cell dimensions is a timeconsuming process, there also appears to be potential to estimate cell size from coccolith length (Henderiks and Pagani, 2007; Henderiks, 2008).

Few observations of coccosphere dimensions are reported in the literature for most species, and the number of cells that have been studied to derive the given ranges is rarely reported. Measurements are often from a single geographical location, meaning that size variation between strains is not accounted for. There is additionally inconsistency as to whether the range of coccosphere sizes reported is the full range of sizes that occurs or only those most commonly observed. A further source of uncertainty is the generalisation of at times complex geometry to fit a particular geometric form.

The uncertainty ranges provided around our biomass estimates are intended to reflect the influence of cell size on coccolithophore biomass. Since these are based on cytoplasm dimensions estimated from total coccosphere size, it is unclear whether biomass values towards the high end of our uncertainty range are biologically realistic. We may expect larger coccospheres to be characterised by a greater proportion of inorganic carbon rather than reflecting a constant ratio of cytoplasm : coccosphere dimensions. 
(a)

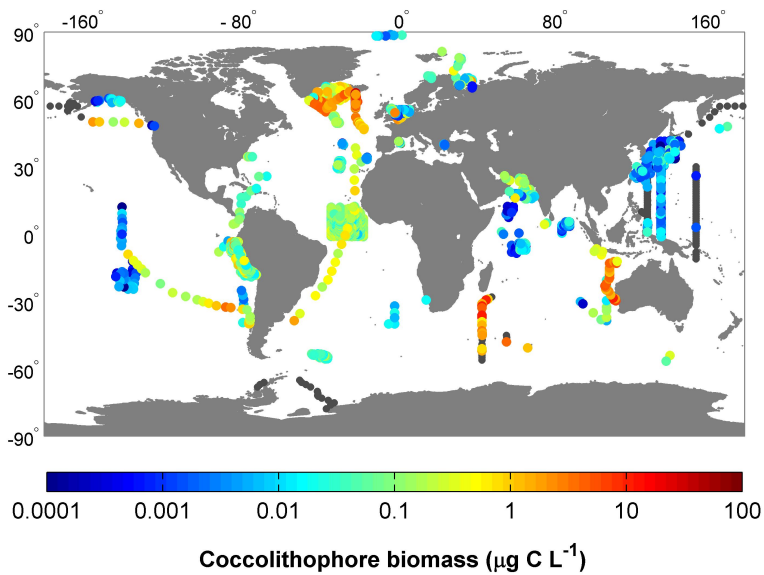

(b)

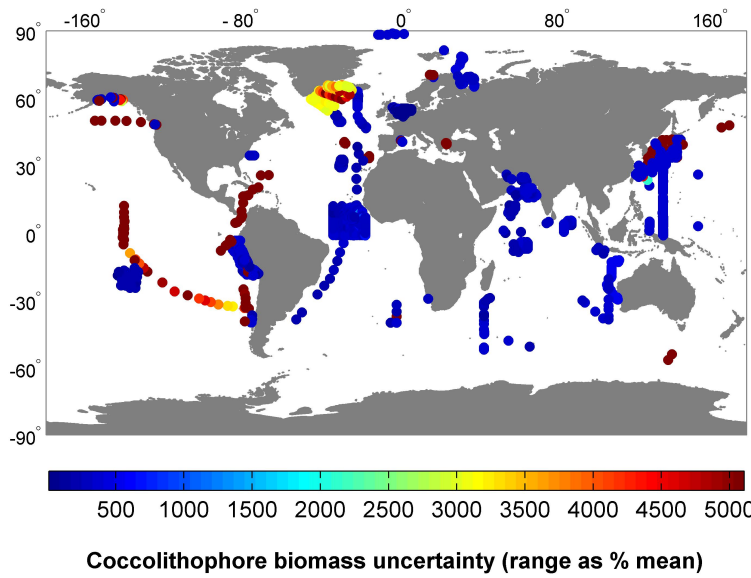

Figure 8. (a) Surface $(0-5 \mathrm{~m})$ mean coccolithophore biomass $\left(\mu \mathrm{gCL}^{-1}\right)$ and (b) range of uncertainty in cell biomass estimates (\% of the mean) due to uncertainty in cell size.

While our uncertainty ranges are very high, a comparison of our mean biomass estimates to previously published coccolithophore biomass values shows strong consistency: our highest mean biomass estimates (i.e., those associated with large E. huxleyi blooms: maximum of $127 \mu \mathrm{g} \mathrm{CL}-1$ ) are similar to past estimates from light microscopy-based cell counts (e.g. Holligan et al., 1993: $130 \mu \mathrm{g} \mathrm{CL}^{-1}$ ), but slightly lower than coccolithophore biomass estimates from fatty acid biomarkers in mesocosm experiments (de Kluijver et al., 2010: $190 \mu \mathrm{g} \mathrm{CL}{ }^{-1}$ ).

In addition to the errors introduced by the biomass conversion process, a considerable degree of uncertainty is already associated with the cell abundance data. Coccolithophores can be quantified using several techniques, including visual or automated identification from scanning electron microscopy, regular light microscopy and light microscopy using cross-polarised light. Additionally, samples can be prepared for light microscopy either by filtration or by using the Utermöhl sedimentation method (Utermöhl, 1958). Reid (1980) and Bollmann et al. (2002) both concluded that inverted light microscopy is unreliable for determining cell densities of small coccolithophores.

Despite these limitations, the Utermöhl method of sedimentation and inverted light microscopy remains widely used in studies investigating phytoplankton assemblages, and any compilation of global coccolithophore distributions would be incomplete without these data. Cell counts from SEM can additionally be unreliable at high cell densities, where shedded coccoliths can lead to difficulties in distinguishing individual coccospheres (A. Poulton, personal observation). The synthesis of datasets obtained from these different methods would be greatly improved by further comparative studies similar to those carried out by Bollmann et al. (2002), as it is currently unclear to what extent small and rare species are being overlooked in different ocean regions as a result of these methodological differences.

Users of the gridded data file should also take into consideration the sparse nature of the original data. Often monthly mean gridded values have been derived from relatively few individual datapoints that do not represent the full range of values that occur in a given location. We expect to see a bias toward higher biomass values, given that studies are often conducted in locations and times of year when blooms are expected to occur.

We have not included estimates of inorganic carbon content in the database, as we do not feel that useful estimates of coccolithophore calcite can currently be provided from the abundance data. The ratio of inorganic : organic carbon has been shown to vary considerably with environmental and growth conditions (Zondervan, 2007), with ratios for the species E. huxleyi alone ranging from 0.26 to 2.3 (van Bleijswijk et al., 1994; Paasche, 2002). While some estimates have been made of the relationship between inorganic and organic carbon for $E$. huxleyi-dominated communities (e.g. Fernández et al., 1993; Poulton et al., 2010), the relationship of calcite content to biomass for other coccolithophore communities remains less well understood.

The biomass estimates presented here represent a first attempt to assess global coccolithophore biomass distributions. While we recognise that the uncertainties associated with these biomass estimates are significant, we nevertheless feel that they provide a more informative dataset than would a compilation of abundance data alone given the large size variation among coccolithophore species. The coccolithophores present particular challenges for the compilation and synthesis of diverse datasets due to the wide range of methods used for their quantification as well as the limited understanding of cell dimensions. The strong biases associated with the different methods highlight the need for coccolithophore abundance data to be published alongside appropriate metadata to allow users to assess data quality. 


\section{Conclusions}

This database represents the largest effort to date to compile coccolithophore abundance observations and provide standardised biomass estimates to the scientific community. We report our biovolume and biomass conversion procedures in detail and discuss the associated uncertainties. We anticipate that this dataset, together with others from the MAREDAT special issue, will be a valuable resource for studies of plankton distributions and ecology and in particular for the evaluation and development of marine ecosystem models. While data are clearly lacking for certain regions, the dataset nevertheless represents the largest available compilation of global coccolithophore abundance and biomass. We hope to improve the spatial and temporal coverage of the dataset as well as the accuracy of biomass conversions as additional data become available in the future.

\section{Appendix A}

\section{A1 Data table}

A full data table containing all biomass data points can be downloaded from the data archive PANGAEA (doi:10.1594/PANGAEA.785092). The data file contains longitude, latitude, depth, sampling time, abundance counts and biomass concentrations, as well as the full data references.

\section{A2 Gridded netcdf biomass product}

Monthly mean biomass data have been gridded onto a $360 \times$ $180^{\circ}$ grid, with a vertical resolution of 33 depth levels (equivalent to World Ocean Atlas depths) and a temporal resolution of 12 months (climatological monthly means). This dataset is provided in netcdf format for easy use in model evaluation exercises. The netcdf file can be downloaded from PANGAEA (doi:10.1594/PANGAEA.785092). This file contains total and non-zero abundance and biomass values. For all fields, the means, medians and standard deviations resulting from multiple observations in each of the $1^{\circ}$ pixels are given. The ranges in biomass values due to uncertainties in cell size are not included as variables in the netcdf product, but are given as ranges (minimum cell biomass, maximum cell biomass) in the data table. 


\section{A3 Biomass conversion details}

Table A3. Biomass conversion details for coccolithophore taxa reported in the database: biovolume category (best available taxonomic description, species names corrected where possible); number of datapoints ( $n$, flagged and unflagged data); coccosphere shape $(\mathrm{S}=$ sphere, $\mathrm{PS}=$ prolate spheroid, $\mathrm{C}=$ cone, $\mathrm{CY}=$ cylinder, $\mathrm{DC}=$ double cone, $\mathrm{V}=$ various shapes, $\mathrm{L}=$ species dimensions unknown, cell biovolume estimate from literature); minimum, maximum and mean coccosphere dimensions $(\mu \mathrm{m})$, cell biovolume $\left(\mu \mathrm{m}^{3}\right)$ and cell biomass $\left(\mathrm{pgCL}^{-1}\right)$.

\begin{tabular}{|c|c|c|c|c|c|c|c|c|c|c|c|c|c|c|c|c|c|c|}
\hline \multirow[t]{2}{*}{ Biovolume Category } & \multirow[t]{2}{*}{$n$} & Shape & & imeter & $\mu \mathrm{m})$ & & ength $(\mu$ & & & Vidth $(\mu$ & & Bio & volume & $\left(\mu \mathrm{m}^{3}\right)$ & Biom & ass (pg C & $\left(\right.$ cell $\left.^{-1}\right)$ & References \\
\hline & & & Min & $\operatorname{Max}$ & Mean & Min & Max & Mean & Min & $\operatorname{Max}$ & Mean & Min & $\operatorname{Max}$ & Mean & Min & Max & Mean & \\
\hline Acanthoica sp. & 199 & PS & & & & & & & & & & 61 & 126 & 85 & 9 & 18 & 12 & \\
\hline Acanthoica acanthifera & 130 & PS & & & & 6.0 & 7.0 & 6.5 & 5.0 & 5.0 & 5.0 & 17 & 20 & 18 & 3 & 3 & 3 & 4,16 \\
\hline Acanthoica janchenii & 5 & PS & & & & & & 7.0 & & & 6.5 & 17 & 70 & 33 & 3 & 10 & 5 & 16 \\
\hline Acanthoica ornata & 4 & PS & & & & 14.0 & 16.0 & 15.0 & 11.0 & 12.0 & 11.5 & 192 & 261 & 224 & 26 & 34 & 30 & 26 \\
\hline Acanthoica quattrospina & 1446 & PS & & & & 7.0 & 15.0 & 11.0 & 5.0 & 9.5 & 7.3 & 20 & 153 & 65 & 3 & 21 & 10 & $4,9,10,11,12,16$ \\
\hline Algirosphaera cucullata & 25 & $\mathrm{~S}$ & 8.0 & 11.0 & 9.5 & & & & & & & 58 & 151 & 97 & 9 & 21 & 14 & 4,16 \\
\hline Algirosphaera robusta & 448 & $\mathrm{~S}$ & 6.5 & 16.0 & 11.3 & & & & & & & 31 & 463 & 161 & 5 & 57 & 22 & $4,9,10,11,12,16,25$ \\
\hline Alisphaera sp. & 60 & $\mathrm{~s}$ & & & & & & & & & & 75 & 211 & 125 & 11 & 28 & 18 & \\
\hline Alisphaera extenta & 45 & $\mathrm{~s}$ & 6.5 & 10.0 & 8.3 & & & & & & & 31 & 113 & 64 & 5 & 16 & 10 & 17 \\
\hline Alisphaera gaudii & 45 & $\mathrm{~S}$ & 11.0 & 12.0 & 11.5 & & & & & & & 151 & 195 & 172 & 21 & 26 & 23 & 17 \\
\hline Alisphaera ordinata & 67 & $\mathrm{~s}$ & 10.0 & 12.0 & 11.0 & & & & & & & 113 & 195 & 151 & 16 & 26 & 21 & 17 \\
\hline Alisphaera pinnigera & 70 & $\mathrm{~s}$ & 7.0 & 13.0 & 10.0 & & & & & & & 39 & 248 & 113 & 6 & 32 & 16 & 4,17 \\
\hline Alisphaera spatula & 25 & $\mathrm{~s}$ & & & 11.0 & & & & & & & 75 & 316 & 151 & 11 & 40 & 21 & 5 \\
\hline Alisphaera unicornis & 165 & $\mathrm{~s}$ & 7.3 & 12.0 & 9.7 & & & & & & & 44 & 195 & 102 & 7 & 26 & 15 & $4,9,10,22$ \\
\hline Alveosphaera bimurata & 67 & DC & & & & & & 18.0 & & & 8.0 & 33 & 137 & 65 & 5 & 19 & 10 & 22 \\
\hline Anacanthoica acanthos & 50 & PS & & & & 8.0 & 12.5 & 10.3 & 7.0 & 7.0 & 7.0 & 44 & 69 & 57 & 7 & 10 & 9 & $4,11,16,26$ \\
\hline Anacanthoica cidaris & 25 & $\mathrm{~S}$ & & & 13.0 & & & & & & & 124 & 522 & 248 & 17 & 63 & 32 & 16 \\
\hline Anthosphaera sp. & 305 & $\mathrm{~S}$ & 4.5 & 16.0 & 10.3 & & & & & & & 10 & 463 & 122 & 2 & 57 & 17 & $4,10,18$ \\
\hline Anthosphaera fragaria & 141 & $\mathrm{~s}$ & 4.5 & 7.0 & 5.8 & & & & & & & 10 & 39 & 22 & 2 & 6 & 4 & $4,10,18$ \\
\hline Braarudosphaera sp. & 6 & $\mathrm{~S}$ & 5.0 & 16.0 & 10.5 & & & & & & & 14 & 463 & 131 & 2 & 57 & 18 & \\
\hline Braarudosphaera bigelowii & 1034 & $\mathrm{~s}$ & 5.0 & 16.0 & 10.5 & & & & & & & 14 & 463 & 131 & 2 & 57 & 18 & 8,10 \\
\hline Calcidiscus sp. & 83 & $\mathrm{~s}$ & 5.0 & 28.0 & 16.5 & & & & & & & 64 & 1432 & 364 & 10 & 157 & 46 & \\
\hline Calcidiscus leptoporus & 967 & $\mathrm{~s}$ & 5.0 & 28.0 & 16.5 & & & & & & & 14 & 2483 & 508 & 2 & 257 & 62 & $4,9,10,11,15$ \\
\hline Calcidiscus quadriperforatus & 67 & $\mathrm{~S}$ & 10.0 & 15.0 & 12.5 & & & & & & & 113 & 382 & 221 & 16 & 48 & 29 & $4,10,11$ \\
\hline Calcioconus sp. & 7 & $\mathrm{C}$ & & & & 15.0 & 18.0 & 16.5 & 10.0 & 12.0 & 11.0 & 85 & 147 & 113 & 12 & 20 & 16 & \\
\hline Calcioconus vitreus & 17 & $\mathrm{C}$ & & & & 15.0 & 18.0 & 16.5 & 10.0 & 12.0 & 11.0 & 85 & 147 & 113 & 12 & 20 & 16 & 26 \\
\hline Calciopappus sp. & 122 & $\mathrm{C}$ & & & & & & & & & & 18 & 44 & 29 & 3 & 7 & 5 & \\
\hline Calciopappus caudatus & 49 & $\mathrm{C}$ & & & & 26.0 & 36.0 & 31.0 & 3.5 & 4.0 & 3.8 & 18 & 33 & 25 & 3 & 5 & 4 & 10 \\
\hline Calciopappus rigidus & 181 & $\mathrm{C}$ & & & & 9.0 & 12.0 & 10.5 & 6.0 & 9.0 & 7.5 & 18 & 55 & 33 & 3 & 8 & 5 & $4,10,12$ \\
\hline Calciosolenia sp. & 61 & $\mathrm{~V}$ & & & & & & & & & & 31 & 817 & 240 & 5 & 95 & 31 & \\
\hline Calciosolenia brasiliensis & 1394 & DC & & & & 33.0 & 100.0 & 66.5 & 4.0 & 8.0 & 6.0 & 30 & 362 & 135 & 5 & 46 & 19 & $1,4,9,10,12,19$ \\
\hline Calciosolenia murrayi & 1311 & $\mathrm{CY}$ & 3.0 & 10.0 & 6.5 & 21.0 & 75.0 & 48.0 & & & & 32 & 1272 & 344 & 5 & 141 & 43 & $1,4,9,10,11,12$ \\
\hline Calicasphaera blokii & 45 & $\mathrm{~S}$ & 6.5 & 7.7 & 7.1 & & & & & & & 31 & 52 & 40 & 5 & 8 & 6 & 15 \\
\hline Calicasphaera concava & 45 & $\mathrm{~S}$ & 7.0 & 11.0 & 9.0 & & & & & & & 39 & 151 & 82 & 6 & 21 & 12 & 15 \\
\hline Calicasphaera diconstricta & 25 & $\mathrm{~s}$ & 6.2 & 8.5 & 7.4 & & & & & & & 27 & 69 & 45 & 4 & 10 & 7 & 15 \\
\hline Calyptrolithina divergens & 67 & PS & & & & 5.5 & 8.0 & 6.8 & 5.5 & 6.0 & 5.8 & 19 & 33 & 25 & 3 & 5 & 4 & 10 \\
\hline Calyptrolithina multipora & 92 & $\mathrm{~S}$ & 13.9 & 22.5 & 18.2 & & & & & & & 304 & 1288 & 682 & 39 & 143 & 80 & 10,15 \\
\hline Calyptrolithina wettsteinii & 45 & PS & & & & 12.5 & 15.8 & 14.2 & 10.7 & 13.0 & 11.9 & 162 & 302 & 225 & 22 & 39 & 30 & 11,15 \\
\hline Calyptrolithophora gracillima & 1 & PS & & & & 9.5 & 18.0 & 13.8 & 9.0 & 16.0 & 12.5 & 87 & 521 & 243 & 13 & 63 & 32 & 4,10 \\
\hline Calyptrolithophora papillifera & 141 & S & 9.0 & 20.0 & 14.5 & & & & & & & 82 & 905 & 345 & 12 & 104 & 44 & $4,10,11$ \\
\hline Calyptrosphaera sp. & 820 & $\mathrm{~S}$ & 5.0 & 22.0 & 13.5 & & & & & & & 254 & 484 & 350 & 33 & 59 & 44 & \\
\hline Calyptrosphaera globosa & 4 & S & 17.0 & 20.0 & 18.5 & & & & & & & 556 & 905 & 716 & 67 & 104 & 84 & 26 \\
\hline Calyptrosphaera incisa & 1 & $\mathrm{~S}$ & & & 10.0 & & & & & & & 57 & 238 & 113 & 9 & 31 & 16 & 26 \\
\hline Calyptrosphaera insignis & 8 & $\mathrm{~s}$ & 11.0 & 14.0 & 12.5 & & & & & & & 151 & 310 & 221 & 21 & 40 & 29 & 26 \\
\hline Caneosphaera sp. & 15 & $\mathrm{~s}$ & 4.5 & 18.0 & 11.3 & & & & & & & 10 & 660 & 161 & 2 & 78 & 22 & $4,9,10,11,22$ \\
\hline Canistrolithus sp. & 74 & $\mathrm{~s}$ & 14.3 & 23.8 & 19.0 & & & & & & & 327 & 1515 & 776 & 42 & 165 & 90 & 4 \\
\hline Ceratolithus sp. & 6 & $\mathrm{~S}$ & 7.0 & 18.9 & 13.0 & & & & & & & 39 & 764 & 246 & 6 & 89 & 32 & \\
\hline Ceratolithus cristatus & 107 & $S$ & 7.0 & 18.9 & 13.0 & & & & & & & 39 & 764 & 246 & 6 & 89 & 32 & $4,10,22$ \\
\hline Coccolithus sp. & 1191 & $\mathrm{~s}$ & 8.0 & 22.0 & 15.0 & & & & & & & 58 & 1204 & 382 & 9 & 134 & 48 & \\
\hline Coccolithus pelagicus & 1108 & $\mathrm{~S}$ & 8.0 & 22.0 & 15.0 & & & & & & & 58 & 1204 & 382 & 9 & 134 & 48 & $9,10,11$ \\
\hline Coccolithus pelagicus holo & 625 & $\mathrm{~s}$ & 8.0 & 18.0 & 13.0 & & & & & & & 58 & 660 & 248 & 9 & 78 & 32 & 10 \\
\hline Corisphaera sp. & 40 & $\mathrm{~S}$ & 4.5 & 9.2 & 6.9 & & & & & & & 15 & 52 & 28 & 3 & 8 & 5 & \\
\hline Corisphaera gracilis & 93 & $\mathrm{~s}$ & & & 6.5 & & & & & & & 16 & 65 & 31 & 3 & 10 & 5 & 10 \\
\hline Corisphaera strigilis & 49 & $\mathrm{~s}$ & 5.0 & 7.0 & 6.0 & & & & & & & 14 & 39 & 24 & 2 & 6 & 4 & 4 \\
\hline Coronosphaera sp. & 626 & $\mathrm{~S}$ & 12.0 & 53.0 & 32.5 & & & & & & & 222 & 509 & 345 & 29 & 62 & 44 & \\
\hline Coronosphaera binodata & 4 & $\mathrm{~s}$ & 13.0 & 16.0 & 14.5 & & & & & & & 248 & 463 & 345 & 32 & 57 & 44 & 4,26 \\
\hline Coronosphaera mediterranea & 544 & $\mathrm{~S}$ & 12.0 & 17.0 & 14.5 & & & & & & & 195 & 556 & 345 & 26 & 67 & 44 & $4,9,10$ \\
\hline Cribrosphaera sp. & 15 & $\mathrm{~s}$ & & & 8.3 & & & & & & & 32 & 136 & 65 & 5 & 19 & 10 & 23 \\
\hline Cribrosphaera ehrenbergii & 5 & $\mathrm{~s}$ & & & 8.3 & & & & & & & 32 & 136 & 65 & 5 & 19 & 10 & 23 \\
\hline Crystallolithus sp. & 11 & $\mathrm{~S}$ & 8.0 & 20.0 & 14.0 & & & & & & & 58 & 905 & 310 & 9 & 104 & 40 & 10 \\
\hline Cyrtosphaera aculeata & 93 & $\mathrm{~S}$ & & & 7.0 & & & & & & & 19 & 81 & 39 & 3 & 12 & 6 & $4,10,16$ \\
\hline Cyrtosphaera lecaliae & 45 & $\mathrm{~S}$ & & & 9.0 & & & & & & & 41 & 173 & 82 & 6 & 23 & 12 & 16 \\
\hline Discosphaera sp. & 152 & $\mathrm{~s}$ & 4.5 & 14.0 & 10.0 & & & & & & & 10 & 310 & 113 & 2 & 40 & 16 & \\
\hline Discosphaera tubifera & 1312 & $\mathrm{~s}$ & 4.5 & 14.0 & 10.0 & & & & & & & 10 & 310 & 113 & 2 & 40 & 16 & $1,4,9,10,11,12,16$ \\
\hline Emiliania huxleyi & 5651 & $S$ & 3.5 & 15.0 & 9.3 & & & & & & & 5 & 382 & 90 & 1 & 48 & 13 & $1,4,9,10,11,12,14,22$ \\
\hline Florisphaera profunda var. elongata & 49 & $\mathrm{~s}$ & & & 12.0 & & & & & & & 98 & 410 & 195 & 14 & 51 & 26 & $4,10,12,24,25$ \\
\hline Florisphaera profunda var. profunda & 536 & $\mathrm{~S}$ & 4.0 & 12.0 & 8.0 & & & & & & & 7 & 195 & 58 & 1 & 26 & 9 & 25 \\
\hline Gephyrocapsa sp. & 909 & $\mathrm{~s}$ & 2.6 & 15.0 & 8.8 & & & & & & & 22 & 121 & 50 & 4 & 17 & 8 & \\
\hline Gephyrocapsa ericsonii & 254 & $\mathrm{~S}$ & 3.0 & 5.0 & 4.0 & & & & & & & 3 & 14 & 7 & 1 & 2 & 1 & $4,9,10,25$ \\
\hline Gephyrocapsa muellerae & 49 & $\mathrm{~S}$ & 7.0 & 8.0 & 7.5 & & & & & & & 39 & 58 & 48 & 6 & 9 & 7 & 4 \\
\hline Gephyrocapsa oceanica & 933 & $\mathrm{~s}$ & 5.0 & 15.0 & 10.0 & & & & & & & 14 & 382 & 113 & 2 & 48 & 16 & $4,6,9,10,11,12$ \\
\hline Gephyrocapsa ornata & 422 & $\mathrm{~s}$ & 3.3 & 4.5 & 3.9 & & & & & & & 31 & 31 & 31 & 5 & 5 & 5 & 4,10 \\
\hline Gephyrocapsids & 9 & $\mathrm{~s}$ & 2.6 & 15.0 & 8.8 & & & & & & & 19 & 165 & 56 & 3 & 22 & 9 & \\
\hline Gladiolithus flabellatus & 245 & S & 8.0 & 12.0 & 10.0 & & & & & & & 58 & 195 & 113 & 9 & 26 & 16 & 4 \\
\hline
\end{tabular}


Table A3. Continued.

\begin{tabular}{|c|c|c|c|c|c|c|c|c|c|c|c|c|c|c|}
\hline Biovolume Category & $n$ & Shape & & imeter & $\mu \mathrm{m})$ & & ength ( & & & Vidth ( & & Bio & volume & $\left(\mu \mathrm{m}^{3}\right)$ \\
\hline & & & Min & $\operatorname{Max}$ & Mean & Min & $\operatorname{Max}$ & Mean & Min & Max & Mean & Min & $\operatorname{Max}$ & Mean \\
\hline Halopappus sp. & 582 & $\mathrm{~V}$ & & & & & & & & & & 65 & 273 & 132 \\
\hline Halopappus quadribrachiatus & 6 & $\mathrm{~S}$ & 5.0 & 8.0 & 6.5 & & & & & & & 14 & 58 & 31 \\
\hline Halopappus vahseli & 8 & $\mathrm{C}$ & & & & & & 21.0 & & & 14.0 & 116 & 489 & 233 \\
\hline Heimiella excentrica & 18 & $\mathrm{~S}$ & 18.0 & 24.0 & 21.0 & & & & & & & 660 & 1563 & 1047 \\
\hline Helicosphaera sp. & 398 & $\mathrm{~V}$ & & & & & & & & & & 150 & 672 & 340 \\
\hline Helicosphaera carteri & 553 & PS & & & & 10.0 & 28.0 & 19.0 & 13.0 & 20.0 & 16.5 & 191 & 1267 & 585 \\
\hline Helicosphaera carteri (holo) & 67 & S & 10.0 & 15.5 & 12.8 & & & & & & & 113 & 421 & 234 \\
\hline Helicosphaera hyalina & 109 & PS & & & & 12.0 & 22.0 & 17.0 & 11.0 & 18.0 & 14.5 & 164 & 806 & 404 \\
\hline Helicosphaera pavimentum & 131 & PS & & & & 10.5 & 13.5 & 12.0 & 10.5 & 12.5 & 11.5 & 131 & 239 & 179 \\
\hline Helicosphaera wallichii & 49 & S & & & & & & 14.7 & & & 13.4 & 149 & 627 & 299 \\
\hline Helladosphaera sp. & 60 & PS & & & & 4.9 & 9.0 & 7.0 & 4.0 & 6.4 & 5.2 & 9 & 42 & 21 \\
\hline Helladosphaera cornifera & 158 & PS & & & & 4.9 & 9.0 & 7.0 & 4.0 & 6.4 & 5.2 & 9 & 42 & 21 \\
\hline Holococcolithophora sphaeroidea & 100 & S & 6.0 & 12.0 & 9.0 & & & & & & & 24 & 195 & 82 \\
\hline Homozygosphaera sp. & 45 & $\mathrm{~S}$ & 6.0 & 15.0 & 10.5 & & & & & & & 41 & 315 & 131 \\
\hline Homozygosphaera arethusae & 45 & $\mathrm{~S}$ & 6.0 & 15.0 & 10.5 & & & & & & & 24 & 382 & 131 \\
\hline Homozygosphaera triarcha & 92 & $\mathrm{~S}$ & 8.0 & 13.0 & 10.5 & & & & & & & 58 & 248 & 131 \\
\hline Lohmannosphaera sp. & 4 & $\mathrm{~S}$ & 6.0 & 12.0 & 9.0 & & & & & & & 24 & 195 & 82 \\
\hline Lohmannosphaera adriatica & 32 & $\mathrm{~S}$ & 10.0 & 12.0 & 11.0 & & & & & & & 113 & 195 & 151 \\
\hline Lohmannosphaera paucoscyphos & 18 & $\mathrm{~S}$ & & & 8.0 & & & & & & & 29 & 122 & 58 \\
\hline Michaelsarsia sp. & 18 & $\mathrm{~V}$ & & & & & & & & & & 77 & 573 & 247 \\
\hline Michaelsarsia adriaticus & 270 & PS & & & & 10.0 & 30.0 & 20.0 & 8.0 & 15.0 & 11.5 & 72 & 763 & 299 \\
\hline Michaelsarsia elegans & 200 & S & 9.0 & 15.0 & 12.0 & & & & & & & 82 & 382 & 195 \\
\hline Michaelsarsia splendens & 32 & $\mathrm{~S}$ & & & 12.0 & & & & & & & 98 & 410 & 195 \\
\hline Navilithus altivelum & 45 & $\mathrm{~S}$ & 5.0 & 8.0 & 6.5 & & & & & & & 14 & 58 & 31 \\
\hline Oolithotus sp. & 39 & $\mathrm{~S}$ & & & & & & & & & & 60 & 1651 & 364 \\
\hline Oolithotus antillarum & 301 & $\mathrm{~S}$ & 10.0 & 13.0 & 11.5 & & & & & & & 113 & 248 & 172 \\
\hline Oolithotus fragilis & 579 & S & 4.0 & 30.0 & 17.0 & & & & & & & 7 & 3054 & 556 \\
\hline Ophiaster sp. & 101 & $\mathrm{~S}$ & 3.5 & 10.5 & 7.0 & & & & & & & 5 & 131 & 39 \\
\hline Ophiaster hydroideus & 1748 & $\mathrm{~S}$ & 3.5 & 8.0 & 5.8 & & & & & & & 5 & 58 & 22 \\
\hline Palusphaera vandelii & 145 & $\mathrm{~S}$ & 4.0 & 8.7 & 6.4 & & & & & & & 7 & 74 & 29 \\
\hline Pappomonas sp. & 294 & $\mathrm{~V}$ & & & & & & & & & & 21 & 894 & 1331 \\
\hline Pappomonas flabellifera & 25 & PS & & & & 4.5 & 7.5 & 6.0 & 3.0 & 5.0 & 4.0 & 5 & 21 & 11 \\
\hline Papposphaera sp. & 192 & $\mathrm{~S}$ & 4.0 & 16.0 & 10.0 & & & & & & & 9 & 48 & 23 \\
\hline Papposphaera borealis & 67 & $S$ & & & 7.0 & & & & & & & 7 & 58 & 24 \\
\hline Papposphaera lepida & 165 & $\mathrm{~S}$ & 4.5 & 16.0 & 10.3 & & & & & & & 10 & 39 & 22 \\
\hline Picarola margalefii & 94 & $\mathrm{~S}$ & 6.0 & 12.0 & 9.0 & & & & & & & 24 & 195 & 82 \\
\hline Pleurochrysis carterae & 32 & $\mathrm{~S}$ & 12.0 & 17.0 & 14.5 & & & & & & & 195 & 556 & 345 \\
\hline Pleurochrysis roscoffensis & 8 & $\mathrm{~S}$ & 12.0 & 20.0 & 16.0 & & & & & & & 195 & 905 & 463 \\
\hline Polycrater galapagensis & 141 & $\mathrm{~S}$ & 9.8 & 15.8 & 12.8 & & & & & & & 106 & 446 & 237 \\
\hline Pontosphaera sp. & 114 & $\mathrm{~V}$ & & & & & & & & & & 261 & 1056 & 551 \\
\hline Pontosphaera discopora & 2 & $\mathrm{~S}$ & 17.0 & 28.0 & 22.5 & & & & & & & 556 & 2483 & 1288 \\
\hline Pontosphaera echinofera & 5 & PS & & & & & & 16.0 & & & 12.0 & 195 & 821 & 391 \\
\hline Pontosphaera haeckelli & 2 & $\mathrm{~S}$ & 11.0 & 15.0 & 13.0 & & & & & & & 151 & 382 & 248 \\
\hline Pontosphaera inermis & 1 & S & 7.0 & 9.0 & 8.0 & & & & & & & 39 & 82 & 58 \\
\hline Pontosphaera nigra & 42 & PS & & & & 20.0 & 24.0 & 22.0 & 14.0 & 16.0 & 15.0 & 443 & 695 & 560 \\
\hline Pontosphaera ovalis & 1 & $\mathrm{~S}$ & 5.0 & 6.0 & 5.5 & & & & & & & 14 & 24 & 19 \\
\hline Pontosphaera stagnicola & 1 & $\mathrm{~S}$ & 14.0 & 20.0 & 17.0 & & & & & & & 310 & 905 & 556 \\
\hline Pontosphaera syracusana & 555 & $\mathrm{~S}$ & 15.0 & 30.0 & 22.5 & & & & & & & 382 & 3054 & 1288 \\
\hline Poricalyptra sp. & 45 & $\mathrm{~V}$ & & & & & & & & & & 43 & 200 & 103 \\
\hline Poricalyptra aurisinae & 67 & $\mathrm{~S}$ & 7.0 & 12.0 & 9.5 & & & & & & & 39 & 195 & 97 \\
\hline Poricalyptra magnaghii & 92 & PS & & & & 10.0 & 13.5 & 11.8 & 6.5 & 11.6 & 9.1 & 48 & 205 & 109 \\
\hline Poritectolithus sp. & 70 & $\mathrm{~S}$ & 6.8 & 14.0 & 10.4 & & & & & & & 35 & 310 & 126 \\
\hline Poritectolithus poritectus & 70 & $\mathrm{~S}$ & & & 9.0 & & & & & & & 41 & 173 & 82 \\
\hline Reticulofenestra parvula & 159 & $\mathrm{~S}$ & 3.0 & 3.8 & 3.4 & & & & & & & 3 & 6 & 4 \\
\hline Reticulofenestra sessilis & 284 & $\mathrm{~S}$ & 6.0 & 10.5 & 8.3 & & & & & & & 24 & 131 & 64 \\
\hline Rhabdosphaera sp. & 295 & $\mathrm{~S}$ & 4.0 & 12.0 & 8.0 & & & & & & & 202 & 252 & 223 \\
\hline Rhabdosphaera ampullacea & 1 & S & 6.8 & 7.3 & 7.1 & & & & & & & 36 & 44 & 40 \\
\hline Rhabdosphaera clavigera & 1641 & S & 7.9 & 12.0 & 10.0 & & & & & & & 56 & 195 & 111 \\
\hline Rhabdosphaera hispida & 46 & $\mathrm{~S}$ & 10.0 & 12.0 & 11.0 & & & & & & & 113 & 195 & 151 \\
\hline Rhabdosphaera tignifer & 2 & $\mathrm{~L}$ & & & & & & & & & & 800 & 800 & 800 \\
\hline Rhabdosphaera xiphos & 212 & $\mathrm{~S}$ & 4.0 & 6.0 & 5.0 & & & & & & & 7 & 24 & 14 \\
\hline Scyphosphaera apsteinii & 414 & $\mathrm{~S}$ & 18.0 & 25.0 & 21.5 & & & & & & & 660 & 1767 & 1124 \\
\hline Solisphaera sp. & 45 & $\mathrm{~S}$ & 5.0 & 9.4 & 7.2 & & & & & & & 17 & 76 & 39 \\
\hline Solisphaera blagnacensis & 45 & $\mathrm{~S}$ & 5.6 & 9.4 & 7.5 & & & & & & & 20 & 93 & 48 \\
\hline Solisphaera emidasius & 45 & $\mathrm{~S}$ & 5.0 & 8.0 & 6.5 & & & & & & & 14 & 58 & 31 \\
\hline Sphaerocalyptra sp. & 45 & S & 5.0 & 22.0 & 13.5 & & & & & & & 14 & 1204 & 278 \\
\hline Sphaerocalyptra adenensis & 71 & $\mathrm{~S}$ & 5.5 & 8.5 & 7.0 & & & & & & & 19 & 69 & 39 \\
\hline Sphaerocalyptra quadridentata & 68 & $\mathrm{~S}$ & 5.0 & 9.0 & 7.0 & & & & & & & 14 & 82 & 39 \\
\hline Syracolithus sp. & 47 & $\mathrm{~S}$ & 10.0 & 19.0 & 14.5 & & & & & & & 113 & 776 & 345 \\
\hline Syracolithus dalmaticus & 29 & $\mathrm{~S}$ & 10.0 & 19.0 & 14.5 & & & & & & & 113 & 776 & 345 \\
\hline Syracosphaera sp. & 1249 & $\mathrm{~S}$ & & & & & & & & & & 92 & 598 & 246 \\
\hline Syracosphaera ampliora & 25 & $\mathrm{~S}$ & 5.6 & 10.2 & 7.9 & & & & & & & 20 & 120 & 56 \\
\hline Syracosphaera anthos & 183 & $\mathrm{~S}$ & 7.0 & 13.0 & 10.0 & & & & & & & 39 & 248 & 113 \\
\hline Syracosphaera anthos holo & 2 & $\mathrm{~S}$ & & & 15.0 & & & & & & & 191 & 802 & 382 \\
\hline Syracosphaera bannockii & 112 & $\mathrm{~S}$ & 5.0 & 7.0 & 6.0 & & & & & & & 14 & 39 & 24 \\
\hline Syracosphaera borealis & 49 & $\mathrm{~S}$ & 6.5 & 8.2 & 7.4 & & & & & & & 31 & 62 & 45 \\
\hline Syracosphaera brandtii & 43 & $\mathrm{~S}$ & 12.0 & 15.0 & 13.5 & & & & & & & 195 & 382 & 278 \\
\hline Syracosphaera corolla & 141 & $\mathrm{~S}$ & 9.8 & 11.6 & 10.7 & & & & & & & 641 & 641 & 641 \\
\hline Syracosphaera cupulifera & 3 & $\mathrm{~S}$ & & & 10.0 & & & & & & & 57 & 238 & 113 \\
\hline Syracosphaera delicata & 45 & $\mathrm{~S}$ & 6.5 & 7.5 & 7.0 & & & & & & & 31 & 48 & 39 \\
\hline Syracosphaera dentata & 19 & $\mathrm{~S}$ & 5.0 & 17.0 & 11.0 & & & & & & & 14 & 556 & 151 \\
\hline Syracosphaera dilatata & 117 & $S$ & 9.0 & 14.0 & 11.5 & & & & & & & 82 & 310 & 172 \\
\hline
\end{tabular}


Table A3. Continued.

\begin{tabular}{|c|c|c|c|c|c|c|c|c|c|c|c|c|c|c|c|c|c|c|}
\hline \multirow[t]{2}{*}{ Biovolume Category } & \multirow[t]{2}{*}{$n$} & \multirow[t]{2}{*}{ Shape } & \multicolumn{3}{|c|}{ Diameter $(\mu \mathrm{m})$} & \multicolumn{3}{|c|}{ Length $(\mu \mathrm{m})$} & \multicolumn{3}{|c|}{ Width $(\mu \mathrm{m})$} & \multicolumn{3}{|c|}{ Biovolume $\left(\mu \mathrm{m}^{3}\right)$} & \multicolumn{3}{|c|}{ Biomass (pg C cell ${ }^{-1}$ ) } & \multirow[t]{2}{*}{ References } \\
\hline & & & Min & $\operatorname{Max}$ & Mean & Min & Max & Mean & Min & $\operatorname{Max}$ & Mean & Min & $\operatorname{Max}$ & Mean & Min & Max & Mean & \\
\hline Syracosphaera epigrosa & 117 & $\mathrm{~S}$ & 8.0 & 13.0 & 10.5 & & & & & & & 58 & 248 & 131 & 9 & 32 & 18 & 22 \\
\hline Syracosphaera exigua & 94 & $\mathrm{~S}$ & 7.5 & 11.7 & 9.6 & & & & & & & 48 & 181 & 100 & 7 & 24 & 14 & 22 \\
\hline Syracosphaera grundii & 38 & $\mathrm{~S}$ & 8.0 & 10.0 & 9.0 & & & & & & & 58 & 113 & 82 & 9 & 16 & 12 & 26 \\
\hline Syracosphaera halldalii & 116 & $\mathrm{~S}$ & 6.0 & 18.0 & 12.0 & & & & & & & 24 & 660 & 195 & 4 & 78 & 26 & $4,9,10,22$ \\
\hline Syracosphaera histrica & 273 & PS & & & & 10.8 & 20.0 & 15.4 & 9.0 & 14.0 & 11.5 & 99 & 443 & 230 & 14 & 55 & 30 & 10,22 \\
\hline Syracosphaera lamina & 165 & PS & & & & 12.0 & 47.0 & 29.5 & 12.5 & 23.5 & 18.0 & 212 & 2936 & 1081 & 28 & 299 & 122 & $9,11,22$ \\
\hline Syracosphaera marginaporata & 165 & S & 3.0 & 6.0 & 4.5 & & & & & & & 3 & 24 & 10 & 1 & 4 & 2 & 5 \\
\hline Syracosphaera molischii & 1083 & $\mathrm{~S}$ & 4.5 & 11.3 & 7.9 & & & & & & & 10 & 163 & 56 & 2 & 22 & 8 & $4,9,10,11,22$ \\
\hline Syracosphaera nana & 106 & $\mathrm{~S}$ & 5.5 & 8.2 & 6.9 & & & & & & & 19 & 62 & 36 & 3 & 9 & 6 & 4,22 \\
\hline Syracosphaera nodosa & 248 & $\mathrm{~S}$ & 6.5 & 20.0 & 13.3 & & & & & & & 31 & 905 & 263 & 5 & 104 & 34 & $4,10,22$ \\
\hline Syracosphaera noroitica & 70 & $\mathrm{~S}$ & 9.0 & 11.0 & 10.0 & & & & & & & 82 & 151 & 113 & 12 & 21 & 16 & 22 \\
\hline Syracosphaera orbiculus & 165 & $\mathrm{~S}$ & 6.0 & 9.3 & 7.7 & & & & & & & 24 & 91 & 51 & 4 & 13 & 8 & 22 \\
\hline Syracosphaera ossa & 141 & $\mathrm{~S}$ & 6.0 & 8.3 & 7.2 & & & & & & & 24 & 65 & 41 & 4 & 10 & 6 & 4,22 \\
\hline Syracosphaera pirus & 240 & PS & & & & 6.0 & 18.0 & 12.0 & 6.0 & 10.0 & 8.0 & 24 & 204 & 87 & 4 & 27 & 13 & $9,10,12,22$ \\
\hline Syracosphaera prolongata & 511 & $\mathrm{C}$ & & & & 10.0 & 70.0 & 40.0 & 7.0 & 8.0 & 7.5 & 55 & 507 & 254 & 8 & 62 & 33 & $4,10,11,22$ \\
\hline Syracosphaera pulchra & 1531 & PS & & & & 5.0 & 70.0 & 37.5 & 10.0 & 23.0 & 16.5 & 57 & 4188 & 1155 & 9 & 411 & 129 & $1,4,9,10,11,12$ \\
\hline Syracosphaera pulchra (holo) & 257 & S & 8.0 & 28.0 & 18.0 & & & & & & & 58 & 2483 & 660 & 9 & 257 & 78 & 10,11 \\
\hline Syracosphaera rotula & 116 & $\mathrm{~S}$ & 5.0 & 7.2 & 6.1 & & & & & & & 14 & 42 & 26 & 2 & 7 & 4 & $4,10,22$ \\
\hline Syracosphaera schilleri & 1 & $\mathrm{~S}$ & & & 15.0 & & & & & & & 191 & 802 & 382 & 26 & 93 & 48 & 26 \\
\hline Syracosphaera spinosa & 2 & $\mathrm{~S}$ & 8.0 & 9.5 & 8.8 & & & & & & & 58 & 97 & 76 & 9 & 14 & 11 & 26 \\
\hline Syracosphaera subsalsa & 5 & PS & & & & 20.0 & 28.0 & 24.0 & 14.0 & 18.0 & 16.0 & 443 & 1026 & 695 & 55 & 116 & 82 & 26 \\
\hline Syracosphaera tumularis & 94 & S & 10.0 & 20.0 & 15.0 & & & & & & & 113 & 905 & 382 & 16 & 104 & 48 & 4 \\
\hline Thoracosphaera heimii & 33 & $\mathrm{~S}$ & 12.0 & 12.6 & 12.3 & & & & & & & 195 & 226 & 210 & 26 & 30 & 28 & 25 \\
\hline Turrilithus latericioides & 206 & $\mathrm{~S}$ & 8.0 & 11.0 & 9.5 & & & & & & & 58 & 151 & 97 & 9 & 21 & 14 & 4 \\
\hline Umbellosphaera sp. & 690 & $\mathrm{~S}$ & 9.2 & 16.0 & 12.6 & & & & & & & 101 & 422 & 224 & 14 & 52 & 30 & \\
\hline Umbellosphaera irregularis & 1079 & $\mathrm{~S}$ & 10.0 & 15.0 & 12.5 & & & & & & & 113 & 382 & 221 & 16 & 48 & 29 & 9 \\
\hline Umbellosphaera tenuis & 420 & $\mathrm{~S}$ & 9.2 & 16.0 & 12.6 & & & & & & & 88 & 463 & 226 & 13 & 57 & 30 & $4,10,11$ \\
\hline Umbilicosphaera sp. & 1968 & $\mathrm{~S}$ & 8.5 & 43.0 & 25.8 & & & & & & & 84 & 3825 & 929 & 12 & 379 & 106 & \\
\hline Umbilicosphaera foliosa & 46 & $\mathrm{~S}$ & 10.0 & 18.0 & 14.0 & & & & & & & 113 & 660 & 310 & 16 & 78 & 40 & $4,10,13,22,25$ \\
\hline Umbilicosphaera hulburtiana & 289 & PS & & & & 8.5 & 28.0 & 18.3 & 8.5 & 24.0 & 16.3 & 69 & 1824 & 545 & 10 & 195 & 66 & 4,10 \\
\hline Umbilicosphaera sibogae & 1601 & $\mathrm{~S}$ & 8.5 & 43.0 & 25.8 & & & & & & & 69 & 8992 & 1931 & 10 & 818 & 205 & $1,4,9,10,11,12,22$ \\
\hline Zygosphaera sp. & 1 & $\mathrm{~S}$ & 6.0 & 15.0 & 10.5 & & & & & & & 32 & 163 & 80 & 5 & 22 & 12 & \\
\hline Zygosphaera amoena & 45 & $\mathrm{~S}$ & 5.0 & 7.0 & 6.0 & & & & & & & 14 & 39 & 24 & 2 & 6 & 4 & 4 \\
\hline Zygosphaera hellenica & 120 & $\mathrm{~S}$ & 8.0 & 15.0 & 11.5 & & & & & & & 58 & 382 & 172 & 9 & 48 & 23 & $4,10,11,12,15,25$ \\
\hline Zygosphaera marsilii & 27 & $\mathrm{~S}$ & 6.0 & 8.5 & 7.3 & & & & & & & 24 & 69 & 43 & 4 & 10 & 7 & 4,10 \\
\hline
\end{tabular}

References: (1) Avancini et al. (2006), (2) Bollmann et al. (2006), (3) Bottino (1978), (4) Cros and Fortuño (2002), (5) Cros i Miguel (2002), (6) Doan-Nhu and Larsen (2010), (7) Gayral and Fresnel (1976), (8) Hagino et al. (2000), (9) Hallegraeff (1984), (10) Heimdal (1997), (11) Heimdal and Saugestad (2002), (12) Hernandez-Becerril and Bravo-Sierra (2001), (13) Inouye and Pienaar (1984), (14) Klaveness (1972), (15) Kleijne (1991), (16) Kleijne (1992), (17) Kleijne et al. (2002), (18) Lecal (1967), (19) Malinverno (2004),

(20) Manton and Oates (1975), (21) Manton et al. (1976), (22) Okada and McIntyre (1977), (23) Priewalder (1973), (24) Quinn et al. (2005), (25) Reid (1980), (26) Schiller (1930), (27) Vilicic (1985), (28) Young and Andruleit (2006), (29) Young et al. (2003)

Acknowledgements. We wish to thank Philipp Assmy, Greta Fryxell, Dimitri Gutiérrez, Patrick Holligan, Catherine Jeandel, Ian Joint, Kalliopi Pagou, Sergey Piontkovski, Tatjana Ratkova, Ralf Schiebel, Mary Silver, Paul Tett, Jahn Throndsen and Paul Wassmann for granting permission to use and redistribute coccolithophore data, the BODC, JGOFS, OBIS, OCB-DMO, PANGAEA, WOD09 and the Observatoire Océanologique de Villefranche databases for providing and archiving data, Erik Buitenhuis for producing the gridded dataset, Scott Doney for assistance with the quality control procedure and Stéphane Pesant for archiving the data. The research leading to these results has received funding from the European Community's Seventh Framework Programme (FP7 2007-2013) under grant agreement number (238366). M. Vogt, J. A. Peloquin and N. Gruber acknowledge funding from ETH Zurich.

Edited by: D. Carlson

\section{References}

Ajani, P., Lee, R., Pritchard, T., and Krogh, M.: Phytoplankton dynamics at a long-term coastal station off Sydney, Australia, J. Coastal Res., 34, 60-73, 2001.
Aktan, Y., Luglie, A., Aykulu, G., and Sechi, N.: Species composition, density and biomass of coccolithophorids in the Istanbul Strait, Turkey, Pak. J. Bot., 35, 45-52, 2003.

Anderson, T. R.: Plankton functional type modelling: running before we can walk?, J. Plankton Res., 27, 1073-1081, doi:10.1093/plankt/fbi076, 2005.

Andruleit, H.: Living coccolithophores recorded during the onset of upwelling conditions off Oman in the western Arabian Sea, J. Nannoplankton Res., 27, 1-14, 2005.

Andruleit, H.: Status of the Java upwelling area (Indian Ocean) during the oligotrophic Northern Hemisphere winter monsoon season as revealed by coccolithophores, Mar. Micropaleontol., 64, 36-51, doi:10.1016/j.marmicro.2007.02.001, 2007.

Andruleit, H., Stäger, S., Rogalla, U., and Cepek, P.: Living coccolithophores in the northern Arabian Sea: ecological tolerances and environmental control, Mar. Micropaleontol., Supplement, 49, 157-181, doi:10.1016/S0377-8398(03)00049-5, 2003.

Assmy, P.: Phytoplankton abundance measured on water bottle samples at stations PS65/424-3, 514-2, 570-4 \& 587-1, Alfred Wegener Institute for Polar and Marine Research, Bremerhaven, doi:10.1594/PANGAEA.603388, doi:10.1594/PANGAEA.603393, doi:10.1594/PANGAEA.603398 and doi:10.1594/PANGAEA.603400, 2007. 
Avancini, M., Cicero, A. M., Di Girolamo, I., Innamorati, M., Magaletti, E., and Sertorio Zunini, T. (Eds.): Guida al riconoscimento del plancton dei mari italiani, Vol. I - Fitoplancton, Ministero dell'Ambiente della Tutela del Territorio e del Mare, ICRAM, 2006.

Beaufort, L., Probert, I., de Garidel-Thoron, T., Bendif, E. M., RuizPino, D., Metzl, N., Goyet, C., Buchet, N., Coupel, P., Grelaud, M., Rost, B., Rickaby, R. E. M., and de Vargas, C.: Sensitivity of coccolithophores to carbonate chemistry and ocean acidification, Nature, 476, 80-83, doi:10.1038/nature10295, 2011.

Bollmann, J., Cortés, M. Y., Haidar, A. T., Brabec, B., Close, A., Hofmann, R., Palma, S., Tupas, L., and Thierstein, H. R.: Techniques for quantitative analyses of calcareous marine phytoplankton, Mar. Micropaleontol., 44, 163-185, doi:10.1016/S0377-8398(01)00040-8, 2002.

Bollmann, J., Cortés, M. Y., Kleijne, A., Ø stergaard, J. B., and Young, J. R.: Solisphaera gen. nov. (Prymnesiophyceae), a new coccolithophore genus from the lower photic zone, Phycologia, 45, 465-477, doi:10.2216/05-14.1, 2006.

Bottino, N.: The effects of arsenate and arsenite on the growth and morphology of the marine unicellular algae Tetraselmis chui (Chlorophyta) and Hymenomonas carterae (Chrysophyta), J. Exp. Mar. Biol. Ecol., 33, 153-168, doi:10.1016/00220981(78)90005-9, 1978.

Brown, C. and Yoder, J.: Coccolithophorid blooms in the global ocean, J. Geophys. Res., 99, 7467-7482, 1994.

Buitenhuis, E. T., Vogt, M., Moriarty, R., Bednaršek, N., Doney, S. C., Leblanc, K., Le Quéré, C., Luo, Y.-W., O’Brien, C., O’Brien, T., Peloquin, J., Schiebel, R., and Swan, C.: MAREDAT: towards a world atlas of MARine Ecosystem DATa, Earth Syst. Sci. Data, Earth Syst. Sci. Data, 5, 227-239, doi:10.5194/essd-5-227-2013, 2013.

Cros, L. and Fortuño, J.: Atlas of northwestern Mediterranean coccolithophores, Sci. Mar., 66 (Suppl. 1), 7-182, 2002.

Cros i Miguel, L.: Planktonic coccolithophores of the NW Mediterranean, Ph.D. thesis, University of Barcelona, 2002.

Doan-Nhu, H. and Larsen, J.: Haptophyte algae of Vietnamese waters. The orders Phaeocystales, Prymnesiales and Isochrysidales (Prymnesiophyceae), Nova Hedwigia, 91, 193-222, doi:10.1127/0029-5035/2010/0091-0193, 2010.

Doney, S. C., Fabry, V. J., Feely, R. A., and Kleypas, J. A.: Ocean acidification: the other $\mathrm{CO}_{2}$ problem, Annual Review of Marine Science, 1, 169-192, doi:10.1146/annurev.marine.010908.163834, 2009.

Dutkiewicz, S., Ward, B. A., Monteiro, F., and Follows, M. J.: Interconnection of nitrogen fixers and iron in the Pacific Ocean: theory and numerical simulations, Global Biogeochem. Cy., 26, 1-16, doi:10.1029/2011GB004039, 2012.

Estrada, M.: Phytoplankton assemblages across a NW Mediterranean front: changes from winter mixing to spring stratification, Oecologia Aquatica, 10, 157-185, 1991.

Estrada, M. and Delgado, M.: Summer phytoplankton distributions in the Weddell Sea, Polar Biol., 10, 441-449, 1990.

Fernández, E., Boyd, P., Holligan, P. M., and Harbour, D. S.: Production of organic and inorganic carbon within a large-scale coccolithophore bloom in the northeast Atlantic Ocean, Mar. Ecol.Prog. Ser., 97, 271-285, 1993.

Frada, M. J., Bidle, K. D., Probert, I., and de Vargas, C.: In situ survey of life cycle phases of the coccolithophore Emilia- nia huxleyi (Haptophyta), Environ. Microbiol., 14, 1558-1569, doi:10.1111/j.1462-2920.2012.02745.x, 2012.

Franklin, D. J., Poulton, A. J., Steinke, M., Young, J., Peeken, I., and Malin, G.: Dimethylsulphide, DMSP-lyase activity and microplankton community structure inside and outside of the Mauritanian upwelling, Prog. Oceanogr., 83, 134-142, doi:10.1016/j.pocean.2009.07.011, 2009.

Fryxell, G.: Abundance and carbon biomass of phytoplankton at station TTOX_X-CTDX, doi:10.1594/PANGAEA.122734 to doi:10.1594/PANGAEA.122756, 2003.

Gayral, P. and Fresnel, J.: Nouvelles observations sur deux Coccolithophoracées marines: Cricosphaera roscoffensis (P. Dangeard) comb. nov. et Hymenomonas globosa (F. Magne) comb. nov., Phycologia, 15, 339-355, 1976.

Glover, D. M., Jenkins, W. J., and Doney, S. C.: Modeling Methods for Marine Science, Cambridge University Press, 2011.

Grados, C., Flores, G., Villanueva, P., Chang, F., and Ayón, P.: Phytoplankton abundance at stations off Paita in August 1995, Piura, Peru, Instituto del Mar del Peru, doi:10.1594/PANGAEA.603265 and doi:10.1594/PANGAEA.603267, 2007.

Hagino, K., Okada, H., and Matsuoka, H.: Spatial dynamics of coccolithophore assemblages in the Equatorial WesternCentral Pacific Ocean, Mar. Micropaleontol., 39, 53-72, doi:10.1016/S0377-8398(00)00014-1, 2000.

Hallegraeff, G. M.: Coccolithophorids (Calcareous Nanoplankton) from Australian Waters, Bot. Mar., 27, 229-248, doi:10.1515/botm.1984.27.6.229, 1984.

Hay, W. W.: Carbonate fluxes and calcareous nannoplankton, in: Coccolithophores: from Molecular Processes to Global Impact, edited by: Thierstein, H. and Young, J., Springer, 509-528, 2004.

Heimdal, B.: Coccolithophores, in: Identifying marine phytoplankton, edited by: Tomas, C. R., Academic Press, San Diego, 1997.

Heimdal, B. R. and Saugestad, A.: Light microscope studies on coccolithophorids from the western Mediterranean Sea, with notes on combination cells of Daktylethra pirus and Syracosphaera pulchra, Plant Biosyst., 136, 3-27, doi:10.1080/11263500212331358491, 2002.

Hernandez-Becerril, D. and Bravo-Sierra, E.: Coccolithophorids from the west coast of Baja California, Mexico, Hydrobiologia, 452, 31-45, 2001

Hillebrand, H., Dürselen, C., Kirschtel, D., Pollingher, U., and Zohary, T.: Biovolume calculation for pelagic and benthic microalgae, J. Phycol., 424, 403-424, 1999.

Hirata, T., Hardman-Mountford, N. J., Brewin, R. J. W., Aiken, J., Barlow, R., Suzuki, K., Isada, T., Howell, E., Hashioka, T., Noguchi-Aita, M., and Yamanaka, Y.: Synoptic relationships between surface Chlorophyll- $a$ and diagnostic pigments specific to phytoplankton functional types, Biogeosciences, 8, 311-327, doi:10.5194/bg-8-311-2011, 2011.

Hofmann, G. E., Barry, J. P., Edmunds, P. J., Gates, R. D., Hutchins, D. A., Klinger, T., and Sewell, M. A.: The effect of Ocean acidification on calcifying organisms in marine ecosystems: an organism-to-ecosystem perspective, Annu. Rev. Ecol. Evol. S., 41, 127-147, doi:10.1146/annurev.ecolsys.110308.120227, 2010.

Holligan, P., Viollier, M., Harbour, D., Camus, P., and ChampagnePhilippe, M.: Satellite and ship studies of coccolithophore production along a continental shelf edge, Nature, 304, 339-342, 
1983.

Holligan, P. M., Fernández, E., Aiken, J., Balch, W. M., Boyd, P., Burkill, P. H., Finch, M., Groom, S. B., Malin, G., Muller, K., Purdie, D. A., Robinson, C., Trees, C. C., Turner, S. M., and van der Wal, P.:A biogeochemical study of the coccolithophore, Emiliania huxleyi, in the North Atlantic, Global Biogeochem. Cy., 7, 879-900, 1993.

Hood, R., Laws, E., Armstrong, R., Bates, N., Brown, C., Carlson, C., Chai, F., Doney, S., Falkowski, P., and Feely, R.: Pelagic functional group modeling: progress, challenges and prospects, Deep-Sea Res. Pt. II, 53, 459-512, doi:10.1016/j.dsr2.2006.01.025, 2006.

Iglesias-Rodríguez, M. D.: Representing key phytoplankton functional groups in ocean carbon cycle models: coccolithophorids, Global Biogeochem. Cy., 16, 1-20, doi:10.1029/2001GB001454, 2002.

Iglesias-Rodríguez, M. D., Halloran, P. R., Rickaby, R. E. M., Hall, I. R., Colmenero-Hidalgo, E., Gittins, J. R., Green, D. R. H., Tyrrell, T., Gibbs, S. J., von Dassow, P., Rehm, E., Armbrust, E. V., and Boessenkool, K. P.: Phytoplankton calcification in a high- $\mathrm{CO}_{2}$ world., Science, 320, 336-340, doi:10.1126/science.1154122, 2008.

Inouye, I. and Pienaar, R.: New observations on the Coccolithophorid Umbilicosphaera sibogae var. foliosa (Prymnesiophyceae) with reference to cell covering, cell structure and flagellar apparatus, Eur. J. Phycol., 19, 357-369, doi:10.1080/00071618400650401, 1984.

Jin, X., Gruber, N., Dunne, J. P., Sarmiento, J. L., and Armstrong, R. A.: Diagnosing the contribution of phytoplankton functional groups to the production and export of particulate organic carbon, $\mathrm{CaCO}_{3}$, and opal from global nutrient and alkalinity distributions, Global Biogeochem. Cy., 20, 1-17, 2006.

Jordan, R., Cros, L., and Young, J.: A revised classification scheme for living haptophytes, Micropaleontology, 50, 55-79, 2004.

Klaveness, D.: Coccolithus huxleyi (Lohm.) Kamptn II. The flagellate cell, aberrant cell types, vegetative propagation and life cycles, Brit. Phycol. J., 3, 309-318, 1972.

Kleijne, A.: Holococcolithophorids from the Indian Ocean, Red Sea, Mediterranean Sea and North Atlantic Ocean, Mar. Micropaleontol., 17, 1-76, doi:10.1016/0377-8398(91)90023-Y, 1991.

Kleijne, A.: Extant Rhabdosphaeraceae (coccolithophorids, class Prymnesiophyceae) from the Indian Ocean, Red Sea, Mediterranean Sea and North Atlantic Ocean, Scripta Geologica, 100, $1-63,1992$.

Kleijne, A., Jordan, R. W., Heimdal, B. R., Samtleben, C., Chamberlain, A. H. L., and Cros, L.: Five new species of the coccolithophorid genus Alisphaera (Haptophyta), with notes on their distribution, coccolith structure and taxonomy, Phycologia, 40, 583-601, doi:10.2216/i0031-8884-40-6-583.1, 2002.

Kopczynska, E. E., Savoye, N., Dehairs, F., Cardinal, D., and Elskens, M.: Spring phytoplankton assemblages in the Southern Ocean between Australia and Antarctica, Polar Biol., 31, 77-88, doi:10.1007/s00300-007-0335-6, 2007.

Langer, G., Geisen, M., Baumann, K.-H., Kläs, J., Riebesell, U., Thoms, S., and Young, J. R.: Species-specific responses of calcifying algae to changing seawater carbonate chemistry, Geochem. Geophy. Geosy., 7, Q09006, doi:10.1029/2005GC001227, 2006.
Le Quéré, C., Harrison, S., Prentice, I., Buitenhuis, E., Aumont, O., Bopp, L., Claustre, H., Da Cunha, L., Geider, R., Giraud, X., Klaas, C., Kohfeld, K., Legendre, L., Manizza, M., Platt, T., Rivkin, R., Sathyendranath, S., Uitz, J., Watson, J., and Wolf-Gladrow, D.: Ecosystem dynamics based on plankton functional types for global ocean biogeochemistry models, Glob. Change Biol., 11, 2016-2040, doi:10.1111/j.13652486.2005.1004.x, 2005.

Lecal, J.: Le Nannoplancton des Côtes d'Israël, Hydrobiologia, 29, 305-387, doi:10.1007/BF00189902, 1967.

Malinverno, E.: Morphological variability within the genus Calciosolenia (coccolithophorids) from the eastern Mediterranean Sea, Micropaleontology, 50, 81-91, 2004.

Manizza, M., Buitenhuis, E. T., and Le Quéré, C.: Sensitivity of global ocean biogeochemical dynamics to ecosystem structure in a future climate, Geophys. Res. Lett., 37, 3-7, doi:10.1029/2010GL043360, 2010.

Manton, I. and Oates, K.: Fine-structural observations on Papposphaera Tangen from the Southern Hemisphere and on Pappomonas gen. nov. from South Africa and Greenland, Brit. Phycol. J., 10, 93-109, doi:10.1080/00071617500650091, 1975.

Manton, I., Sutherland, J., and McCully, M.: Fine structural observations on coccolithophorids from South Alaska in the genera Papposphaera tangen and Pappomonas manton and oates, Eur. J. Phycol., 11, 225-238, doi:10.1080/00071617600650511, 1976.

Marinov, I., Doney, S. C., and Lima, I. D.: Response of ocean phytoplankton community structure to climate change over the $21 \mathrm{st}$ century: partitioning the effects of nutrients, temperature and light, Biogeosciences, 7, 3941-3959, doi:10.5194/bg-7-39412010, 2010.

Marshall, H. G.: Phytoplankton distribution off the North Carolina coast, Am. Midl. Nat., 82, 241-257, doi:10.2307/2423833, 1969.

Menden-Deuer, S. and Lessard, E. J.: Carbon to volume relationships for dinoflagellates, diatoms, and other protist plankton, Limnol. Oceanogr., 45, 569-579, 2000.

Mohan, R., Mergulhao, L. P., Guptha, M., Rajakumar, A., Thamban, M., AnilKumar, N., Sudhakar, M., and Ravindra, R.: Ecology of coccolithophores in the Indian sector of the Southern Ocean, Mar. Micropaleontol., 67, 30-45, doi:10.1016/j.marmicro.2007.08.005, 2008.

O'Brien, C. J., Vogt, M., and Gruber, N., et al.: in preparation, 2013.

Okada, H. and McIntyre, A.: Modern coccolithophores of the Pacific and North Atlantic oceans, Micropaleontology, 23, 1-55, 1977.

Omex I project members and Wassmann, P.: Phytoplankton abundance measured on water bottle samples at station JMX_XX, doi:10.1594/PANGAEA.202662 to doi:10.1594/PANGAEA.202700, 2004.

Paasche, E.: A review of the coccolithophorid Emiliania huxleyi (Prymnesiophyceae), with particular reference to growth, coccolith formation, and calcification-photosynthesis interactions, Phycologia, 40, 503-529, 2002.

Pagou, K. and Assimakopoulou, G.: Abundance of microplankton from bottles SEPT-1999-K1-APRIL-2000K6, Hellenic Center of Marine Research, Institut of Oceanography, Greece, doi:10.1594/PANGAEA.687204 to doi:10.1594/PANGAEA.687209 and doi:10.1594/PANGAEA.688625 to 
Poulton, A. J., Charalampopoulou, A., Young, J. R., Tarran, G. A., Lucas, M. I., and Quartly, G. D.: Coccolithophore dynamics in non-bloom conditions during late summer in the central Iceland Basin (July-August 2007), Limnol. Oceanogr., 55, 1601-1613, doi:10.4319/1o.2010.55.4.1601, 2010.

Priewalder, H.: Die Coccolithophoridenflora des Locus typicus von Pseudotextularia elegans (Rzehak), Reingruberhöhe, Niederösterreich; (Maastricht), Jahrbuch Geologischen Bundesanstalt, 116, 3-34, 1973.

Quinn, P. S., Cortés, M. Y., and Bollmann, J.: Morphological variation in the deep ocean-dwelling coccolithophore Florisphaera profunda (Haptophyta), Eur. J. Phycol., 40, 123 133, doi:10.1080/09670260400024667, 2005.

Ramos, E.: Phytoplankton abundance in surface water in 1992, Ancon, Peru, Universidad Nacional Mayor de San Marcos, doi:10.1594/PANGAEA.465179 to doi:10.1594/PANGAEA.465192, 2006.

Ratkova, T.: ArcOD - Phytoplankton from the White Sea, Barents Sea, Norwegian Sea and Arctic Basin 1993-2003, Ocean Biogeographic Information System, unpublished data, 2012.

Reid, F. M. H.: Coccolithophorids of the North Pacific central gyre with notes on their vertical and seasonal distribution, Micropaleontology, 26, 151-176, 1980.

Riebesell, U. and Zondervan, I.: Reduced calcification of marine plankton in response to increased atmospheric $\mathrm{CO}_{2}$, Nature, 407, 364-367, 2000

Schiebel, R.: Distribution of diatoms, coccolithophores and planktic foraminifers along a trophic gradient during SW monsoon in the Arabian Sea, Mar. Micropaleontol., 51, 345-371, doi:10.1016/j.marmicro.2004.02.001, 2004a.

Schiebel, R.: Distribution of diatoms, coccolithophores and planktic foraminifera in the Arabian Sea, doi:10.1594/PANGAEA.736805, 2004b.

Schiller, J.: Coccolithinae, in: Kryptogamen - flora von Deutschland, Österreich und der Schweiz, edited by Rabenhorst, L., Akademische Verlagsgesellschaft m. b. H., Leipzig, 1930.

Silver, M.: Vertigo KM0414 phytoplankton species data and biomass data: abundance and fluxes from CTDs, Ocean Carbon and Biogeochemistry Data System, OCB DMO, WHOI, 2009.

Smyth, T. J.: Time series of coccolithophore activity in the Barents Sea, from twenty years of satellite imagery, Geophys. Res. Lett., 31, 2-5, doi:10.1029/2004GL019735, 2004.

Stoll, H. M., Klaas, C. M., Probert, I., Ruiz Encinar, J., and Garcia Alonso, J. I.: Calcification rate and temperature effects on Sr partitioning in coccoliths of multiple species of coccolithophorids in culture, Global Planet. Change, 34, 153-171, 2002.

Sun, J.: Geometric models for calculating cell biovolume and surface area for phytoplankton, J. Plankton Res., 25, 1331-1346, doi:10.1093/plankt/fbg096, 2003.

Takahashi, K. and Okada, H.: Environmental control on the biogeography of modern coccolithophores in the Southeastern In- dian Ocean offshore of Western Australia, Mar. Micropaleontol., 39, 73-86, 2000.

Tangen, K., Brand, L. E., Blackwelder, P. L., and Guillard, R. R. L.: Thoracosphaera heimii (Lohmann) Kamptner is a dinophyte: observations on its morphology and life cycle, Mar. Micropaleontol., 7, 193-212, 1982.

Thierstein, H. R. and Young, J. R. (Eds.): Coccolithophores: from Molecular Processes to Global Impact, Springer, 509-528, 2004.

Tyrell, T. and Merico, A.: Emiliania huxleyi: bloom observations and the conditions that induce them, in: Coccolithophores: from Molecular Processes to Global Impact, edited by: Thierstein, H. R. and Young, J., Springer, 75-97, 2004.

Utermöhl, H.: Zur Vervollkommnung der quantitativen Phytoplankton-Methodik, Ver. Theor. Angew. Limnol., 9, 1-38, 1958.

van Bleijswijk, J. D. L., Kempers, R. S., Veldhuis, M. J., and Westbroek, P.: Cell and growth characteristics of types A and B of Emiliania huxleyi (Prymnesiophyceae) as determined by flow cytometry and chemical analyses, J. Phycol., 30, 230-241, 1994.

Verity, P. G., Robertson, C. R., Tronzo, C. R., Andrews, M. G., Nelson, J. R., and Sieracki, M. E.: Relationships between cell volume and the carbon and nitrogen content of marine photosynthetic nanoplankton, Limnol. Oceanogr., 37, 1434-1446, 1992.

Vilicic, D.: An examination of cell volume in dominant phytoplankton species of the central and southern Adriatic Sea, Int. Revue Ges. Hydrobiol., 70, 829-843, 1985.

Vogt, M., Vallina, S. M., Buitenhuis, E. T., Bopp, L., and Le Quéré, C.: Simulating dimethylsulphide seasonality with the dynamic green ocean model PlankTOM5, J. Geophys. Res., 115, 1-21, doi:10.1029/2009JC005529, 2010.

Widdicombe, C. E., Eloire, D., Harbour, D., Harris, R. P., and Somerfield, P. J.: Long-term phytoplankton community dynamics in the Western English Channel, J. Plankton Res., 32, 643655, doi:10.1093/plankt/fbp127, 2010.

Winter, A. and Siesser, W. G. (Eds.): Coccolithophores, Cambridge University Press, New York, 1994.

Young, J., Geisen, M., Cros, L., Kleijne, A., Sprengel, C., Probert, I., and Østergaard, J. B.: A guide to extant coccolithophore taxonomy, Journal of Nannoplankton Research Special Issue 1, 2003.

Young, J. R. and Andruleit, H.: Navilithus altivelum: a remarkable new genus and species of deep photic coccolithophores, J. Micropalaeontol., 25, 141-151, doi:10.1144/jm.25.2.141, 2006.

Zeitzschel, B., Deckers, M., Karrasch, B., Kremling, K., Podewski, S., Stienen, C., and Ullrich, S.: Hydrochemistry and biological data measured on water bottle samples during METEOR cruise M10/2, doi:10.1594/PANGAEA.66713, 2002.

Zondervan, I.: The effects of light, macronutrients, trace metals and $\mathrm{CO}_{2}$ on the production of calcium carbonate and organic carbon in coccolithophores: a review, Deep-Sea Res. Pt. II, 54, 521-537, doi:10.1016/j.dsr2.2006.12.004, 2007. 